\title{
Calibration analysis for water storage variability of the global hydrological model WGHM
}

\author{
S. Werth and A. Güntner \\ Deutsches GeoForschungsZentrum GFZ, Telegrafenberg, 14473 Potsdam, Germany \\ Received: 16 June 2009 - Published in Hydrol. Earth Syst. Sci. Discuss.: 6 July 2009 \\ Revised: 30 November 2009 - Accepted: 1 December 2009 - Published: 11 January 2010
}

\begin{abstract}
The aim of this study is to provide an improved global simulation of continental water storage variations by calibrating the WaterGAP Global Hydrology Model (WGHM) for 28 of the largest river basins worldwide. Five years (January 2003-December 2007) of satellite-based estimates of the total water storage changes from the GRACE mission were combined with river discharge data in a multiobjective calibration framework that uses the most sensitive WGHM model parameters. The uncertainty and significance of the calibration results were analysed with respect to errors in the observation data. An independent simulation period (January 2008-December 2008) was used for validation. The contribution of single storage compartments to the total water budget before and after calibration was analysed in detail. A multi-objective improvement of the model states was obtained for most of the river basins, with mean error reductions of up to $110 \mathrm{~km}^{3} /$ month for discharge and up to $24 \mathrm{~mm}$ of a water mass equivalent column for total water storage changes, such as for the Amazon basin. Errors in the phase and signal variability of seasonal water mass changes were reduced. The calibration is shown to primarily affect soil water storage in most river basins. The variability of groundwater storage variations was reduced on a global scale after calibration. Structural model errors were identified from a small contribution of surface water storage including wetlands in river basins with large inundation areas, such as the Amazon or the Mississippi. Our results demonstrate the value of both the GRACE data and the multi-objective calibration approach for improving large-scale hydrological simulations, and they provide a starting-point for improving model structures. The integration of complimentary observation data to further constrain the simulation of single storage compartments is encouraged.
\end{abstract}

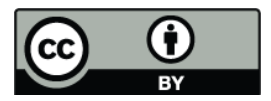

Correspondence to: $\mathrm{S}$. Werth (sawerth@gmail.com)

\section{Introduction}

In the face of global climate change, there is an increase in forecasts about water shortage for many regions of the world and the thread of a water shortage crisis becomes a growing social-humanitarian problem. Global hydrological models are indispensable for tracking the consequences of the alternating climate and for studying the dynamics of the distribution of water resources. Changes in the water budget (change in total water storage $\Delta \mathrm{TWS}=P-E-R$ ) of specific regions, such as in large river basins, play a key role in reliable monitoring of the stability and dynamic behaviour of the water cycle. To simulate the water cycle, hydrological models are constricted by factors such as precipitation $(P)$ and different climatic conditions to estimate the flow and storage of water on the continents and its transfer to other Earth's subsystems including the atmosphere and oceans by the processes of evaporation $(E)$ and runoff $(R)$, respectively. A consistent representation of the continental water cycle and its components are a major issue for hydrological modelling. Only recently, however, have variations in the total water storage (TWS) become key variables in the evaluation of large-scale models (Güntner, 2009).

Several large-scale or global hydrological models exist (some examples are: Dirmeyer et al., 2006; Widen-Nilsson et al., 2007; Liu et al., 2007, 2009; Milly and Shmakin, 2002; Rodell et al., 2004), but the estimates of variations in the TWS greatly differ among them. Werth et al. (2009b) compared global TWS variations (TWSV) of the conceptual WaterGAP Global Hydrological Model (WGHM) with two physically-based land surface models (the Global Land Data Assimilation System, GLDAS and the Land Dynamics model, $\mathrm{LaD}$ ) and discovered differences in the magnitude of the signal itself across the three models even though temporal correlations were high. The reasons for this discrepancy might include different input data and modelling strategies for representing the storage and flow processes at

Published by Copernicus Publications on behalf of the European Geosciences Union. 
an unrefined scale. Additionally, the regional importance and characteristics of individual storage processes remain poorly understood. For example, surface water storage or deeper groundwater are either absent or inattentively considered in many land surface models (Güntner, 2009; Niu et al., 2007).

Syed et al. (2008) assessed TWS variability in the GLDAS and determined that the global variability was too small, concluding that the absence of the consideration of groundwater and surface water, as well as uncertain snow parameterisations, were possible reasons for these modelling errors. TWS amplitudes and phases could be improved in the land surface model, ORCHIDEE, by introducing a cumulative surface water and groundwater reservoir that allows for a longer residence time for water in river basins (Ngo-Duc et al., 2007). Recent regional studies focus on modelling groundwater storage by using land surface models (Gulden et al., 2007; Lo et al., 2008; Kollet and Maxwell, 2008) but groundwater is still absent in several large-scale or global models. Although the global model WGHM simulates the most important storage compartments, including surface water and groundwater, the simulation accuracy of this conceptual model was originally low for river discharge in snowdominated and semi-arid regions. It became clear that it was difficult to represent evaporation and snow accumulation in the WGHM model (Döll et al., 2003). In response, Hunger and Döll (2008) and Schulze and Döll (2004) improved the model equations for both processes. For TWS, however, WGHM still tended to underestimate seasonal TWS variations and phase shifts appeared (Schmidt et al., 2008b, 2006). Güntner et al. (2007) found a regional varying sensitivity of WGHM parameters. Only one parameter from the original model has been globally calibrated thus far. This suggests that an expansion toward a regional calibration of the dominant processes of a river basin is needed.

Theoretical studies propagate an iterative working process of model prediction, model analysis, and process understanding (Fenicia et al., 2008; Savenije, 2009). Simulated states of the water cycle should be compared to real-world observations in order to test whether model predictions are accurate. Model behaviour during tuning processes such as data assimilation (Houtekamer and Mitchell, 1998; Reichle et al., 2002) or model calibration (Duan et al., 2003; Gupta et al., 2005) provides information about process behaviour and structural model deficits. However, the learning process is especially difficult on the global scale and is limited to iterative steps. This challenge is primarily due to a lack of adequate model forcing and validation data that have global coverage and acceptable resolution and accuracy.

In this regard, the Gravity Recovery And Climate Experiment (GRACE) is an extraordinary resource to large-scale hydrological studies. GRACE is a twin-satellite-mission with global coverage and its monthly gravity observations are transformable to the variability of water stored on and below the Earth's surface with a resolution of a few hundred kilometres (Tapley et al., 2004; Wahr et al., 2004).
After compensating the data for atmospheric and oceanic gravity effects, GRACE observations enable temporally reliable studies of different hydrological processes including snow, ice, groundwater, soil, and surface (Wouters et al., 2008; Niu et al., 2007; Swenson et al., 2008; Papa et al., 2008). These observations include different climatic conditions and extreme events across many regions (Zeng et al., 2008; Seitz et al., 2008) or the water balance itself (Sheffield et al., 2009). Since the first GRACE record became available, large progress has been made to improve GRACE data accuracy and as a result the reliability of water mass variations from GRACE has improved. These include studies on de-aliasing (Han et al., 2004), error estimates (Horwath and Dietrich, 2006), the development of filter and decorrelation techniques (Swenson and Wahr, 2002; Kusche, 2007), and filter optimisation (Werth et al., 2009b). Consequently, GRACE is a valuable tool for the validation and calibration of large-scale hydrological models (Schmidt et al., 2008a; Güntner, 2009; Lettenmaier and Famiglietti, 2006). The application of GRACE data for large-scale hydrological modelling began with the validation of simulated water storage variations for large river basins or with global coverage (Ngo-Duc et al., 2007; Syed et al., 2008; Güntner, 2009). More recently, promising steps were made toward the integration of GRACE data into model development and model tuning for particular regions, such as the Amazon or the Mississippi basin (Zaitchik et al., 2008; Werth et al., 2009a; Lo et al., 2010). A worldwide integration of TWS variations that makes full use of the global coverage of GRACE would be desirable to move toward an improved simulation of continental TWSV. However, many combinations of the simulated single storage compartments might lead to a good fit for the integrative GRACE TWS variations but only at a coarse resolution. Hence, to obtain additional model constraints and higher parameter accuracy (Yapo et al., 1998; Vrugt et al., 2003; Gupta et al., 2005), and to reduce parameter equifinality (Beven and Binley, 1992), the combination with other system states, such as river discharge, by using a multi-objective method is promising. In addition, using GRACE-based TWSV and river discharge is of particular interest for water balance analyses since both are integrated measures of the hydrological dynamics in a river basin.

In this context, this study makes a step forward in the iterative learning process of large-scale hydrological modelling toward an improved global simulation of the continental water cycle and its storage compartments by using a multiobjective calibration (Sect. 2.2) of the global model WGHM (Sect. 2.1) against river discharge and GRACE-based estimations (Sect. 2.3) for 28 of the largest and most important river basins worldwide (Sect. 3.1). 


\section{Methods and data}

\subsection{Global hydrological model}

The WaterGAP Global Hydrology Model (WGHM, Döll et al., 2003) simulates the continental water cycle by using conceptual formulations for the most important hydrological processes. WGHM was originally developed by Döll et al. (2003) for water availability studies at the continental scale (Alcamo et al., 2003). However, since the model provides estimates of water masses, it might be useful for hydrological analyses of water storage and its global dynamics (Güntner et al., 2007), as well as for individual storage compartments, such as groundwater recharge (Döll and Fiedler, 2008) or storage of surface water bodies (Papa et al., 2008). WGHM has been repeatedly used for the comparison of continental water storage variability to GRACE-based water mass variations (Schmidt et al., 2006, 2008b).

The conceptual model equations for WGHM are described in detail by Döll et al. (2003), Kaspar (2004), and Hunger and Döll (2008). In general, if water precipitates in the form of rain then it is passed through the storages of interception, surface water (including rivers, reservoirs, lakes and wetlands), soil, and groundwater, and is reduced due to evapotranspiration losses. In cases in which water precipitates as snow, it accumulates as snow storage and follows the above liquid water cycle after melting. Additionally, human water consumption is considered in this water cycle (Döll et al., 2003). Accumulation of ice or permafrost is not accounted for in WGHM (Hunger and Döll, 2008). The model is computed at daily intervals and cell-wise with a $0.5^{\circ}$ spatial resolution, excluding Antarctica and Greenland. Therefore, 66896 grid cells are considered worldwide. Water passes from cell to cell according to a global drainage direction map (Döll and Lehner, 2002) until it reaches a coastal cell, where it discharges to the oceans. The simulations for the hydrological cycle are supplied by cell-based information on the properties of soil, land cover, and hydrogeology as well as on locations of reservoirs, lakes, and, wetlands (Döll et al., 2003).

A very recent version of WGHM is described by Hunger and Döll (2008) and includes updates for the input data for surface water bodies and human water consumption, an improved snow algorithm, and a more realistic formulation of evaporation for lakes and wetlands. To generate model runs for the GRACE period (2002 - to date), the model was forced by using climate data (temperature, cloudiness and number of rainy days per month) from the operational forecasts of the European Centre for Medium-Range Weather Forecasts (ECMWF). Additionally, monthly precipitation input from the Global Precipitation Climatology Centre (GPCC) was used. Precipitation data were corrected for precipitation measurement errors according to Legates and Willmott (1990) and Fiedler and Döll (2007). This model set-up formed the reference for the present study and is hereafter referred to as the original model version.
Döll et al. (2003) and Hunger and Döll (2008) optimised the original WGHM against long-term river discharge by a runoff coefficient parameter, which determines the fraction of effective precipitation that translates into runoff, depending on the saturation of soil water (Eq. 3, Döll et al., 2003). Both studies noted that only calibrating this parameter was not sufficient to get acceptable simulation results for river discharge in some areas. In addition to issues involving other mis-modelled processes, the water balance of lakes and wetlands is not influenced by the runoff coefficient parameter. Therefore, our study calibrates WGHM parameters for all important process formulations in addition to the runoff within a river basin (see Sect. 2.2.1). We consider calibrated parameter values to be effective values that account for nonresolvable features in a large-scale model such as sub-scale variability, input data errors, model structure errors, or simplifications in model equations.

WGHM consists of 36 model parameters that are explained in detail in the publications of the original model versions. An overview of the 21 WGHM parameters that are relevant for this study is provided in Table 1 . The parameter ranges that we used for calibration are based on data from other literature and qualitative reasoning (Kaspar, 2004).

The soil water storage capacity depends on both the soil type and the land cover, and it is regulated by the root depth parameter. This parameter is calibrated as a multiplicative factor (SL-1). Specifically, the particular value for soil storage capacity that is based on the soil and land cover data in each model cell is multiplied by the value of SL-1 (here in the range of 0.5 to 2 , see Table 1). Groundwater storage and outflow is governed by the groundwater base-flow coefficient (GW-1).

Surface water transport can be calibrated by the river velocity (SW-2). Additionally, the surface water flow coefficient (SW-5), as well as the maximum range of water levels in lakes (lake depth, SW-3) and wetlands (wetlands depth, SW-4), determine the storage rates of surface water bodies and are possible calibration parameters for surface water transport processes. Furthermore, the runoff coefficient parameter, which was optimised against river discharge in the original model version, is calibrated as a multiplier (SW-1) in this study.

The potential evapotranspiration is computed in WGHM using Priestley and Taylor's approach in 1972 (PT). The equation is adjusted by the PT-coefficient that differentiates between humid (average relative humidity of $60 \%$ or more, ER-5) and arid regions (average relative humidity less than $60 \%$, ER-6). The net radiation that is required as input for the PT-approach is computed according to Shuttleworth (1993) (see Döll et al., 2003). The radiation proportion parameter (ER-1) is used to determine the radiation fraction of the extraterrestrial radiation that reaches the Earth's surface. The radiation fraction can be reduced by cloud cover and can be subjected to a radiation correction parameter (ER-2). The actual evaporation of open water can be calibrated by the open 
Table 1. Detailed information on the calibration parameter (col. 1; MCWH: maximum canopy water height, MPET: maximum potential evapotranspiration, PT: Priestley-Taylor) is provided by belonging processes and numbering (col. 2; SL: Soil, GW: groundwater, SW: Surface water, ER: Evaporation and Radiation, SN: Snow, IN: Interception), original WGHM value (col. 3), minimum and maximum value (col. 4, 5). Literature references for the model parameter and according equation numbers are provided in columns 6 and 7 .

\begin{tabular}{lllllrr}
\hline Parameter & $\begin{array}{l}\text { Abbrev. } \\
\text { number }\end{array}$ & $\begin{array}{l}\text { Original } \\
\text { value \& unit }\end{array}$ & $\begin{array}{l}\text { Min. } \\
\text { value }\end{array}$ & $\begin{array}{l}\text { Max. } \\
\text { value }\end{array}$ & $\begin{array}{r}\text { Literature } \\
\text { reference }\end{array}$ & $\begin{array}{r}\text { (Eq.) } \\
\text { or page }\end{array}$ \\
\hline Root depth mult. & SL-1 & 1 & 0.5 & 2 & Kaspar (2004) & $(2.26)$ \\
GW baseflow coefficient & GW-1 & $0.01 /$ day & 0.006 & 0.1 & Döll et al. (2003) & $(5)$ \\
Runoff coefficient mult. & SW-1 & 1 & 0.5 & 2 & Döll et al. (2003) & $(3)$ \\
River velocity & SW-2 & $1 \mathrm{~m} / \mathrm{s}$ & 0.05 & 2 & Kaspar (2004) & $(2.38)$ \\
Lake depth & SW-3 & $5 \mathrm{~m}$ & 1 & 20 & Döll et al. (2003) & $(6)$ \\
Wetland depth & SW-4 & $2 \mathrm{~m}$ & 1 & 5 & Döll et al. (2003) & $(6)$ \\
SW baseflow coefficient & SW-5 & $0.01 /$ day & 0.001 & 0.1 & Döll et al. (2003) & $(6)$ \\
Radiation proportion & ER-1 & 0.25 & 0.08 & 0.54 & Kaspar (2004) & $(2.11)$ \\
Radiation correction & ER-2 & 1.0 & 0.7 & 1.3 & Kaspar (2004) & $(2.13)$ \\
Albedo snow & ER-3 & 0.4 & 0.3 & 0.9 & Kaspar (2004) & p. 19 \\
Albedo open water & ER-4 & 0.08 & 0.03 & 0.5 & Kaspar (2004) & p. 15 \\
PT coeff. (humid areas) & ER-5 & 1.26 & 0.885 & 1.65 & Kaspar (2004) & $(2.4)$ \\
PT coeff. (arid areas) & ER-6 & 1.74 & 1.365 & 2.115 & Kaspar (2004) & $(2.4)$ \\
MPET & ER-7 & $10 \mathrm{~mm} / \mathrm{day}$ & 6.25 & 13.75 & Döll et al. (2003) & $(2)$ \\
MCWH & IN-1 & $0.3 \mathrm{~mm}$ & 0.1 & 1.4 & Döll et al. (2003) & $(1)$ \\
Specific leaf area mult. & IN-2 & 1 & -0.2 & 2.2 & Kaspar (2004) & $(2.19)$ \\
Biomass mult. & IN-3 & 1 & 0.25 & 1.75 & Kaspar (2004) & $(2.19)$ \\
Snow freeze temperature & SN-1 & $0{ }^{\circ} \mathrm{C}$ & -1 & 3 & Kaspar (2004) & $(2.22)$ \\
Snow melting temperature & SN-2 & $0{ }^{\circ} \mathrm{C}$ & -3.75 & 3.75 & Güntner et al. (2007) & $(2)$ \\
Degree day factor & SN-3 & 1 & 0.5 & 2 & Güntner et al. (2007) & $(2)$ \\
Temperature gradient & SN-4 & $0.006{ }^{\circ} \mathrm{C} / \mathrm{m}$ & 0.004 & 0.01 & Hunger and Döll (2008) & p. 845 \\
\hline
\end{tabular}

water albedo (ER-4) and sublimation of snow by the snow albedo (ER-3). Land surface evapotranspiration is limited by the maximum potential evapotranspiration (MPET, ER-7) parameter (see Döll et al., 2003).

Interception storage capacity depends on three parameters: The maximum canopy water height (MCWH, IN-1), a specific leaf area multiplier (IN-2), and a biomass multiplier (IN-3).

The rates of snow melting and accumulation depend on land cover and elevation. Snow melting is computed in WGHM by a degree-day approach. The degree-day factor depends on the type of land cover and is calibrated in this study by a multiplicative factor (SN-3). Sub-grid variability of elevation within a 0.5 -degree model cell is represented in WGHM (100 sub-units per $0.5^{\circ}$-cell) and elevation effects are accounted for by a temperature gradient (SN-4). Additional effects on snow storage processes can be adjusted by a cell-averaged snow freeze temperature $(\mathrm{SN}-1)$ and snow melting temperature $(\mathrm{SN}-2)$.

\subsection{Calibration technique}

\subsubsection{Calibration regions and parameter sensitivity}

Due to the limited resolution of GRACE data, the 28 largest and most important river basins worldwide were selected for this study (Fig. 1). With the exception of Volta in western Africa, all basins are larger than $600000 \mathrm{~km}^{2}$ in size (see Table 2). WGHM calibration is carried out separately for each basin.

Güntner et al. (2007) showed that WGHM parameter sensitivity for water storage variations fluctuated across the river basins. This inter-basin variability is due to different climatic conditions as well as land surface properties and therefore has varying relevance for different storage processes. Consequently, for each region, only the sensitive parameters should be calibrated in order to reduce computational costs and to simplify the interpretation of the calibration results. A sensitivity analysis (SA) against TWSV and river discharge was undertaken (see also Werth et al., 2009a) by using the SA approach that was developed by Hornberger and Spear (1981). The parameter sensitivity was analysed using a Latin Hypercube sampling for 2000 parameter sets for all 28 river basins. Applied parameter ranges are given in Table 1 . The resulting six to eight most sensitive parameters for TWSV and river 


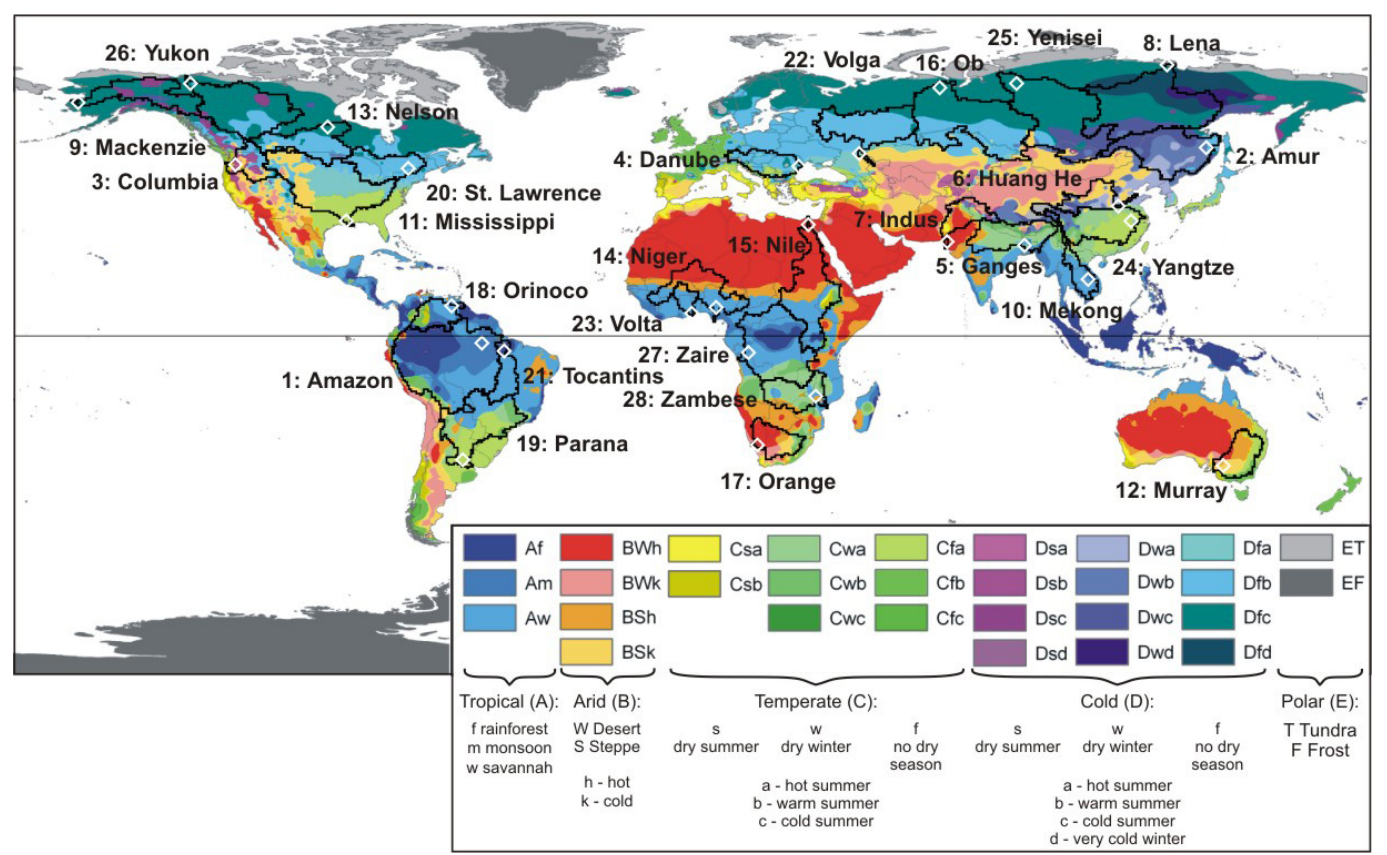

Fig. 1. The 28 largest and most important river basins worldwide (black polygons) with underlying Köppen-Geiger climate zones from 1951-2000 (Peel et al., 2007) and gauging stations (white diamonds) of each basin that was used for the calibration of river discharge. See Table 2 for station names.

discharge (Table 3) were used for the regional calibration of each river basin. Non-sensitive parameters were set to their original values (Table 1, col. 3).

The results of the SA confirmed that the subset of sensitive parameters varied considerably across the river basins. While snow parameters are not sensitive in tropical basins, parameters that control surface water transport appeared to be particularly sensitive in basins with important flood plains, such as the Amazon. A broader range of sensitive parameters was visible in the Indus river basin, which is dominated by snow storage in the northern mountain area and has high evaporation rates in the desert region of the lower Indus. Hence, sensitive parameters belong to these two processes and soil water parameters are comparatively less important in the Indus basin. The important parameters for the Mississippi cover a variety of processes (soil, snow, evaporation, interception, and surface water) because this river basin stretches across three different climate regions (cold in the north, subtropical in the southeast, and dry in the southwest).

\subsubsection{Multi-objective calibration approach}

The Pareto-based multi-objective calibration approach that is used for WGHM was explained in detail by Werth et al. (2009a). Figure 2 and the description below provide an overview of this method. Calibration was performed for all 28 river basins in an automated framework for the period of time spanning January 2003-December 2007.
Calibration is a widely used optimisation technique in hydrological modelling. Different parameter values are tested in an iterative process for their ability to generate model system states that correlate well with observations. The best parameter set provides the lowest simulation error or the highest simulation performance expressed by an objective value. Several functions to measure the objective value are used, such as the normalised root mean square error or the correlation coefficient. In this study, the Nash-Sutcliffe-efficiency coefficient (NSC, Nash and Sutcliffe, 1970) was applied to the data. NSC is a simulation performance measure that normalises the squared difference of a predicted time series to an observed time series by the sum of squared deviations of the observations to their mean value during the period of interest. It ranges from $-\infty$ to 1 (optimal fit), with a value of 0 indicating a simulated time series that performs as well as a model that is equal to the mean of the observable series. NSC is applied here because it measures errors in the phase, amplitude, and mean of a simulated time series simultaneously. NSC is used in this study as an objective value to evaluate both simulated river discharge and water storage time series.

The multi-objective calibration approach makes the selection of the best parameter set less trivial. Due to errors in the model structure and the input data (Vrugt et al., 2003), this approach will no longer provide a single optimal parameter set, but rather produces a Pareto set of optimal solutions (Gupta et al., 1998). Each Pareto solution provides a better simulation performance than any other Pareto solution for at least one of the objectives (but not for all objectives). 
Table 2. Details of the 28 calibrated river basins (col. 1-3) and calibration data (col. 4-6) used. Col. 4: River runoff station, col. 5: Source of discharge data (1: GRDC, 2: US-ACE, 3: ORE-HYBAM) and period runoff data applied for calibration, col. 6: applied GRACE filter method and belonging filter parameter (I: isotropic filter of Swenson and Wahr (2002) for an a-priori given maximum error of basin average $\Delta_{\max }$; II: Swenson and Wahr (2002) computed by the auto-correlation length $G_{l}$ and standard deviation $\sigma_{0}$ of an exponential signal model; III: decorrelation method by Kusche (2007) with the power $x$ for the regularisation factor $a=10^{x}$ of the signal covariance matrix).

\begin{tabular}{|c|c|c|c|c|c|c|}
\hline \multirow{2}{*}{$\begin{array}{l}\text { No. } \\
\text { B1 }\end{array}$} & \multirow{2}{*}{$\begin{array}{c}\text { Basin } \\
\text { Amazon }\end{array}$} & \multirow{2}{*}{$\begin{array}{c}\begin{array}{c}\text { Basin area } \\
{\left[\mathrm{Mio} \mathrm{km}^{2}\right]}\end{array} \\
5.96\end{array}$} & \multirow{2}{*}{$\begin{array}{r}\begin{array}{r}\text { Discharge data } \\
\text { source \& period }\end{array} \\
3: 2003-2007\end{array}$} & \multirow{2}{*}{$\begin{array}{l}\begin{array}{l}\text { Discharge } \\
\text { station }\end{array} \\
\text { Obidos }\end{array}$} & \multicolumn{2}{|c|}{$\begin{array}{l}\text { Filter parameter I) a } \\
\text { II) } \Delta_{\max }, \text { III) } \sigma_{0} / G_{l}\end{array}$} \\
\hline & & & & & III: & $250 / 300$ \\
\hline B2 & Amur & 1.87 & 1: 1975-2004 & Bogorodskoye & II: & 2.5 \\
\hline B3 & Columbia & 0.67 & 1: 1977-2006 & Dalles & I: & 13 \\
\hline B4 & Danube & 0.80 & 1: 1973-2002 & Ceatal Izmail & I: & 12 \\
\hline B5 & Ganges & 1.59 & 1: 1973-2002 & Farakka & I: & 12 \\
\hline B6 & Huang $\mathrm{He}$ & 0.80 & 1: 1973-2002 & Huayuankou & I: & 13 \\
\hline B7 & Indus & 0.85 & 1: 1950-1979 & Kotri & III: & $200 / 1000$ \\
\hline B8 & Lena & 2.45 & 1: 1973-2002 & Stolb & $\mathrm{I}:$ & 12 \\
\hline B9 & Mackenzie & 1.70 & 2: 2003-2007 & Arctic Red River & III: & $150 / 200$ \\
\hline B10 & Mekong & 0.80 & 1: 1980-1991 & Kompong Cham & I: & 12 \\
\hline B11 & Mississippi & 3.24 & 1: 2003-2007 & Tarbert Landing & I: & 12 \\
\hline B12 & Murray & 1.06 & 1: 1965-1984 & Lock 9 & III: & $150 / 900$ \\
\hline B13 & Nelson & 1.20 & 1: 1976-2005 & Kelsey & I: & 12 \\
\hline B14 & Niger & 1.80 & 1: 1977-2006 & Lokoja & $\mathrm{I}:$ & 12 \\
\hline B15 & Nile & 2.91 & 1: 1973-1984 & El Ekhsase & III: & $150 / 900$ \\
\hline B16 & $\mathrm{Ob}$ & 2.70 & 2: 2003-2007 & Salekhard & I: & 13 \\
\hline B17 & Orange & 0.96 & 1: 1972-2001 & Vioolsdrif & III: & $20 / 1000$ \\
\hline B18 & Orinoco & 0.97 & 1: 1960-1989 & Tunente Angostura & II: & 4.1 \\
\hline B19 & Parana & 2.58 & 1: 1965-1994 & Timbues & I: & 12 \\
\hline B20 & St. Lawrence & 1.05 & 1: 1976-2005 & Cornwall & III: & $200 / 1000$ \\
\hline B21 & Tocantins & 0.88 & 1: 1978-1999 & Tucurui & I: & 12 \\
\hline B22 & Volga & 1.39 & 1: 1973-2002 & Volgograd & I: & 13 \\
\hline B23 & Volta & 0.41 & 1: 1955-1984 & Senchi & I: & 13 \\
\hline B24 & Yangtze & 1.93 & 1: 1975-2004 & Datong & I: & 12 \\
\hline B25 & Yenisei & 2.54 & 2: 2003-2007 & Igarka & I: & 14 \\
\hline B26 & Yukon & 0.83 & 1: 1977-2006 & Pilot Stn. & III: & $150 / 100$ \\
\hline B27 & Congo (Zaire) & 3.72 & 1: 1954-1983 & Kinshasa & I: & 13 \\
\hline B28 & Zambezi & 1.39 & 1: 1976-1979 & Matundo-Cais & I: & 12 \\
\hline
\end{tabular}

Without additional information on factors such as the reliability of the observation data or a pre-defined priority of calibration success for one of the objectives, all Pareto solutions are equally valid optimal model runs. In order to define the parameter set after calibration that produced the most balanced model improvement with regard to both objectives (river discharge and TWSV), the Pareto solution that was closest to the optimum of the objectives (here a value of $\mathrm{NSC}=1$ for both objectives) was selected in this study as the best parameter set and was used for further analyses.

The $\epsilon$-Non-dominated Sorting Genetic Algorithm-II ( $\epsilon$-NSGAII, Kollat and Reed, 2006) was used to vary, rank, and archive the parameter sets during the WGHM process. The multi-start scheme and the evolutionary strategy of the algorithm (mutation, crossover, and selection) enable a global optimisation of the parameter values and are able to solve highly non-linear optimisation problems. This algorithm is one of the most efficient and effective multi-objective optimisation methods used in hydrological modelling (Tang et al., 2006). These features enable a Paretobased multi-objective calibration for more than one parameter of the non-linear and computationally expensive WGHM model system. $\epsilon$-NSGAII operators were set to the values proposed by Kollat and Reed (2006), and a population size of $\mathrm{N}=12$, an $\epsilon$-resolution of 0.05 for both objectives, and a generation size of 100 (a maximum of 1200 model evaluations) were used.

In contrast to Werth et al. (2009a), who applied significant signal periods within the GRACE data for their calibration, a calibration against a full time series of GRACE TWSV was undertaken in the present study (see data Sect. 2.3). During the calibration of WGHM, TWSV simulations were filtered in the same way as GRACE data (see Sect. 2.3.2 and Table 2) to ensure equal resolution and a consistent comparison of both data sets. 


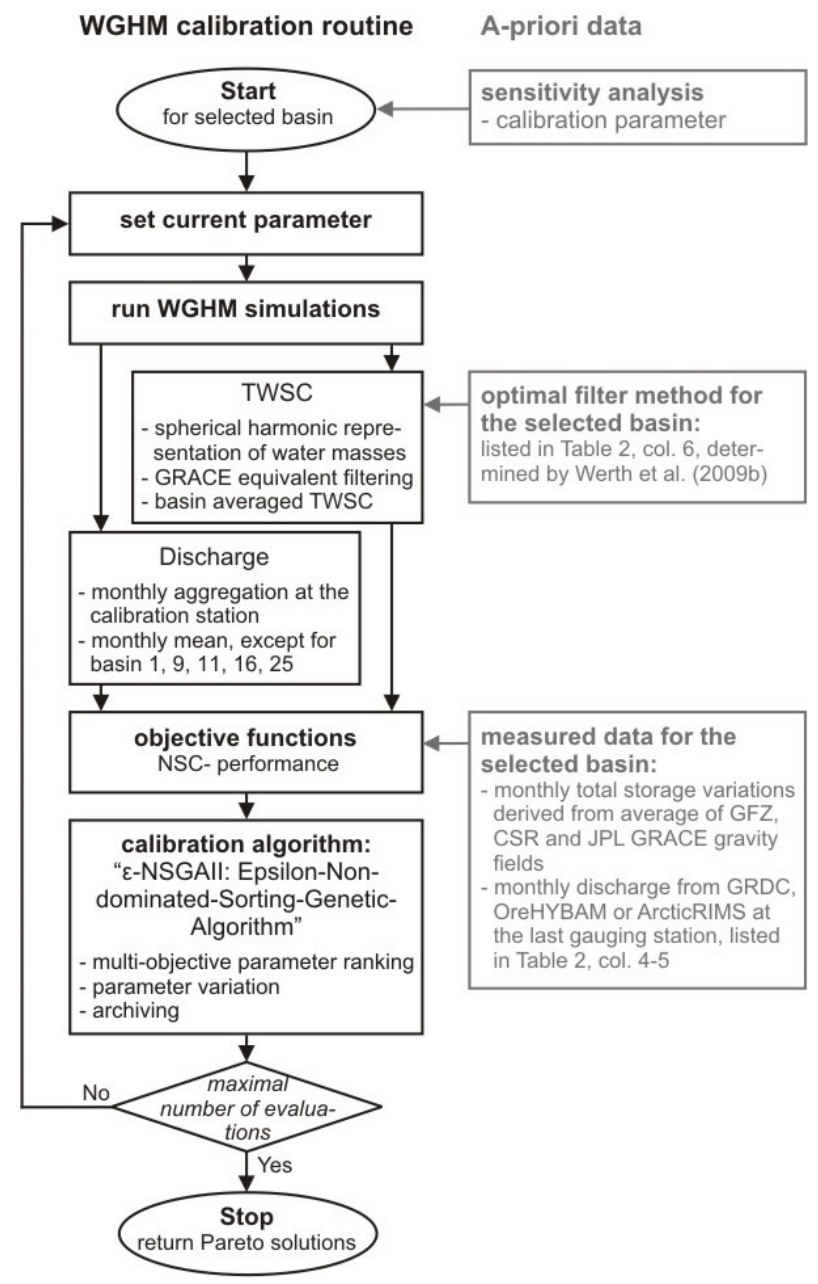

Fig. 2. The concept scheme of multi-objective WGHM calibration for a specific river basin using input from Werth et al. (2009b) for applied GRACE filter methods.

\subsection{Calibration data}

\subsubsection{Discharge data}

River discharge data for the most downstream gauging station of each river basin were used (Table 2, col. 4 and Fig. 1). Data were obtained from the Arctic Regional Integrated Hydrological Monitoring System for the PanArctic Land Mass (ArcticRIMS, http://rims.unh.edu), the Environmental Research Observatory for geodynamical, hydrological and biogeochemical control of erosion/alteration and material transport in the Amazon (ORE HYBAM, http://www.ore-hybam.org/), and the Global Runoff Data Center (GRDC, http://www.bafg.de/GRDC/EN/).

Monthly discharge data were available for the GRACE operation period for the Amazon, Mississippi, Mackenzie, $\mathrm{Ob}$ and Yenisei basins. For all other basins, up-to-date measurements were not available and mean monthly river discharge (for January-December) was computed from the most recent period of available data (maximum period of 30 years, see Table 2 ).

Errors in discharge measurements depend on the individual measurement methods and channel cross-sections are likely to vary for the individual stations and time periods. Unfortunately, the data centres do not provide details on the accuracy of discharge measurements. Therefore, the error in discharge measurements was set to a conservative value of $20 \%$ for the uncertainty analysis of the calibration results.

\subsubsection{GRACE data}

GRACE data used in this study were provided in the form of a monthly spherical harmonic representation of the gravity field (Level-2 products, most recent release RL04) by three different processing centres: the German Research Center for Geosciences (GFZ, until spherical harmonic degree 120), the Center for Space Research (CSR, until degree 60), and the Jet Propulsion Laboratory (JPL until degree 120). Atmospheric and oceanic gravity effects have been removed from the GRACE gravity fields by all centres (Flechtner, 2009). The three data sets show significant differences (see, e.g. the Lena basin in Fig. 3), which are due to different processing strategies, background models, or processing software (Schmidt et al., 2008a). An average of GRACE gravity fields from three processing centres was used for the present study and the differences between the data sets were considered as a measure of uncertainty in GRACE TWSC data (see details below). The three sets of coefficients were averaged from degree 2 to 60 for each month in the period ranging from February 2003 to December 2008, excluding June 2003 and April 2004 due to missing data from GFZ. For GFZ, regularised solutions for July-October 2004 and December 2006 were applied.

The method to transform the spherical harmonic coefficients of GRACE gravity fields to regional averaged water mass variations by Swenson and Wahr (2002) was applied using river basin boundaries (Fig. 1). Long-term trends determined from both the hydrology model WGHM and from the GRACE gravity fields were removed from the TWSV time series in this study.

The filtering of GRACE data is indispensable for separating out GRACE errors from the signal. The spatial resolution of the GRACE data is limited due to the decreasing sensitivity of the satellites to mass variations with smaller geographical coverage. This causes noise in the spherical harmonic coefficients, particularly for higher degrees of the expansion terms, i.e. higher spatial resolution, which is further increased by satellite measurement errors and errors in de-aliasing data (Schmidt et al., 2008a). De-aliasing data refers to mass variations of atmospheric and oceanic circulation models used to reduce sub-monthly circulation effects. Filtering suppresses the noise by down-weighting erroneous coefficients, such as those with higher degrees. At the same time, however, filtering reduces the spatial resolution of the 
Table 3. Most sensitive calibrated parameter for the 28 river basins. See Tables 1 and 2 for complete basin names and parameter description.

\begin{tabular}{|c|c|c|c|c|c|c|c|c|c|}
\hline B1 & B2 & B3 & B4 & B5 & B6 & B7 & B8 & B9 & B 10 \\
\hline SL-1 & SL-1 & SL-1 & SL-1 & SL-1 & SW-1 & SW-1 & SL-1 & SW-1 & SL-1 \\
\hline GW-1 & SW-1 & SW-1 & SW-1 & GW-1 & SW-5 & SW-2 & SW-1 & SW-3 & GW-1 \\
\hline SW-1 & ER-3 & ER-1 & SW-3 & SW-3 & ER-3 & SW-5 & ER-1 & SW-5 & SW-1 \\
\hline SW-2 & ER-1 & ER-3 & ER-1 & SW-4 & IN-1 & ER-1 & ER-3 & ER-3 & SW-2 \\
\hline SW-4 & IN-1 & $\mathrm{SN}-2$ & ER-5 & ER-1 & IN-2 & ER-3 & ER-5 & ER-4 & SW-4 \\
\hline \multirow{3}{*}{ IN-1 } & SN-2 & SN-4 & SN-2 & SN-2 & IN-3 & ER-5 & IN-1 & SN-1 & IN-1 \\
\hline & & & & & & $\mathrm{SN}-2$ & IN-2 & SN-2 & IN-2 \\
\hline & & & & & & SN-4 & SN-2 & SN-3 & IN-3 \\
\hline B11 & B12 & B13 & PB14 & B15 & B16 & B17 & B18 & B19 & B20 \\
\hline SL-1 & GW-1 & SW-1 & SL-1 & SL-1 & SW-1 & GW-1 & SL-1 & SL-1 & SL-1 \\
\hline SW-1 & SW-1 & SW-5 & GW-1 & GW-1 & SW-2 & SW-1 & GW-1 & GW-1 & SW-1 \\
\hline ER-1 & SW-5 & ER-1 & SW-2 & SW-2 & SW-5 & ER-7 & SW-2 & SW-1 & SW-3 \\
\hline ER-5 & ER-2 & ER-3 & SW-4 & SW-3 & ER-2 & IN-1 & SW-5 & SW-3 & ER-4 \\
\hline IN-1 & ER-5 & ER-4 & SW-3 & SW-4 & ER-3 & IN-2 & ER-1 & SW-4 & ER-5 \\
\hline \multirow{3}{*}{$\mathrm{SN}-2$} & ER-6 & ER-5 & ER-1 & ER-1 & SN-1 & IN-3 & IN-2 & SW-5 & IN-1 \\
\hline & IN-1 & SN-2 & IN-2 & ER-3 & SN-2 & & & ER-1 & IN-2 \\
\hline & IN-2 & SN-3 & IN-1 & SN-2 & SN-3 & & & ER-5 & $\mathrm{SN}-2$ \\
\hline B21 & B22 & B23 & B24 & B25 & B26 & B27 & B28 & & \\
\hline SL-1 & SL-1 & SL-1 & SL-1 & ER-1 & SL-1 & SL-1 & SL-1 & & \\
\hline GW-1 & GW-1 & GW-1 & SW-2 & ER-3 & SW-1 & GW-1 & ER-6 & & \\
\hline SW-2 & SW-2 & SW-1 & ER-1 & ER-5 & SW-4 & SW-4 & SW-1 & & \\
\hline SW-3 & SW-3 & SW-2 & ER-3 & SN-1 & ER-1 & SW-5 & SW-3 & & \\
\hline SW-4 & ER-1 & SW-3 & ER-5 & SN-2 & ER-3 & ER-1 & ER-1 & & \\
\hline ER-1 & SN-2 & ER-1 & $\mathrm{SN}-2$ & SN-3 & $\mathrm{SN}-2$ & ER-5 & ER-7 & & \\
\hline ER-4 & & IN-1 & & & & & IN-1 & & \\
\hline $\mathrm{IN}-2$ & & IN-2 & & & & & IN-2 & & \\
\hline
\end{tabular}

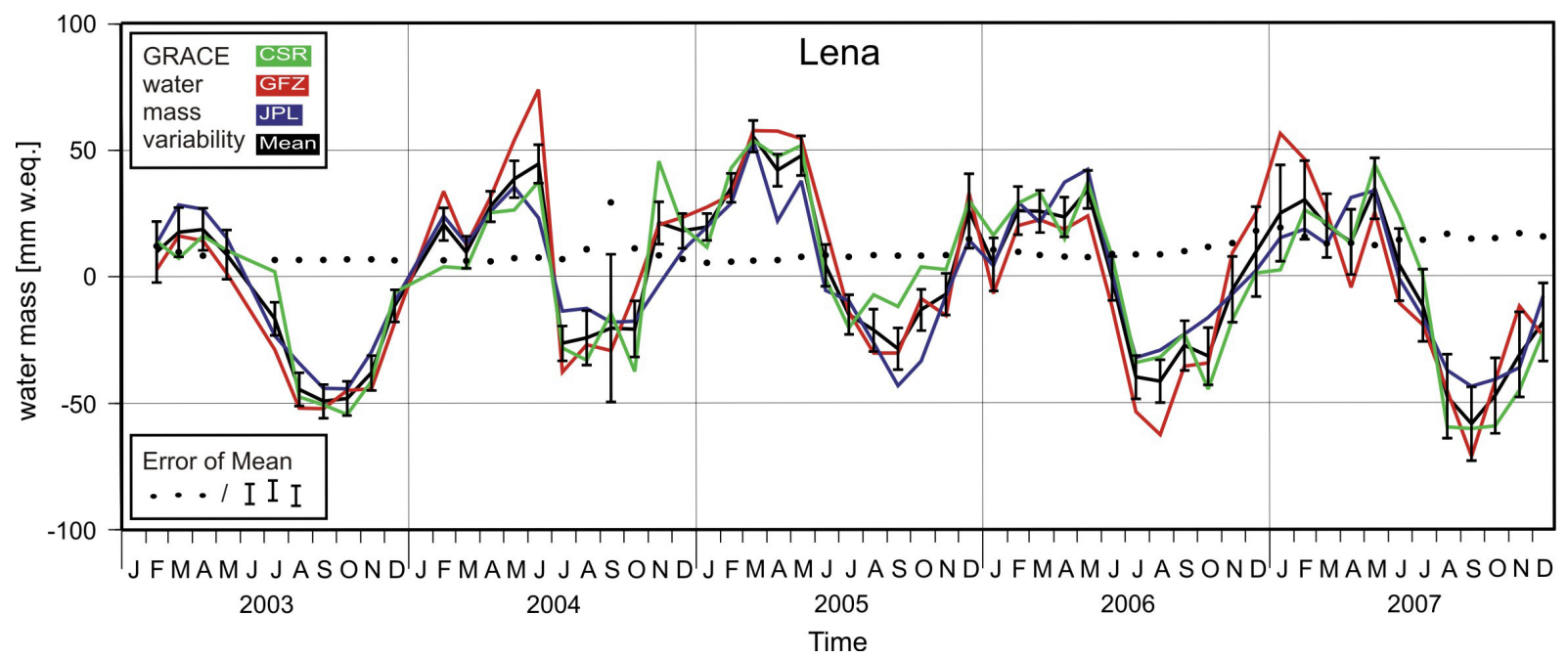

Fig. 3. Basin-averaged time series of TWS variations from GRACE for the Lena river basin from the processing centres CSR (green), GFZ (red), and JPL (blue) and the averaged field (black) with propagated coefficient errors (black dots and error bars). 
data. Consequently, the error budget of derived TWSV is also influenced by signal leakage errors from surrounding areas.

The selection of an optimal filter method that leads to a proper error reduction as well as to a sufficient separation of signal from the region of interest and its neighbouring regions is one of the greatest challenges when resolving GRACE data for TWSV. Filtering might change the final TWSV signal properties and the magnitude of errors varies between particular regions and months. Werth et al. (2009b) showed that filter-induced amplitude damping and phase shifts in the time series of basin-averaged TWSV differs between regions due to varying signal characteristics inside and outside of the river basin as well as the basin shape. Therefore, the user must decide on an adequate filter method and adequate filter parameters for each river basin specifically in order to optimally balance and minimise GRACE measurement errors and leakage errors.

In the present study, the optimal filter methods and filter parameter values of Werth et al. (2009b) were applied to smooth GRACE and hydrological data from 22 river basins. Optimal filter settings were derived by repeating the method that is described by Werth et al. (2009b) for the remaining six basins (Columbia, Huang He, Mekong, Murray, Orinoco and Volta). See Table 2 for a summary of applied filter methods. The optimal spatial resolution varies between 200 and $600 \mathrm{~km}$ (see Werth et al. (2009b), Table 5, col. I with the values for each river basin), though resolutions achieved in the present study are likely to be higher since filtering methods that are more sophisticated than the Gaussian were used for each basin.

All processing centres publish GRACE errors as errors of the spherical harmonic coefficients. Since errors are too optimistic if they are derived from the adjustment equation system that is used to process GRACE gravity fields, the GFZ and CSR processing centres adjust them to apparent signal noise in the spatial domain (Schmidt et al., 2008a; Wahr et al., 2006). Such correlated errors were not available for JPL gravity fields. Therefore, assuming a normal distribution of the GRACE errors, the confidence interval of the JPL coefficient error assessment was increased to $99 \%$ for this study. This results in a $\approx 2.6$-times greater error than the original JPL coefficient errors. According to the law of error propagation, the final error for the averaged coefficients from the three processing centres amounts to:

$$
\epsilon_{k n m}^{\text {avefield }}=\sqrt{\epsilon_{k n m}^{\mathrm{GFZ}^{2}}+\epsilon_{k n m}^{\mathrm{CSR}^{2}}+\epsilon_{k n m}^{\mathrm{JPL}^{2}}},
$$

$k=[0,1], n=[2,60], m=[0,60]$

Subsequently, errors in the coefficients are propagated to basin averages of water storage for each river basin. Figure 3 provides an example of basin-averaged TWSV that is derived from the three gravity solutions, the average solution, and associated errors.

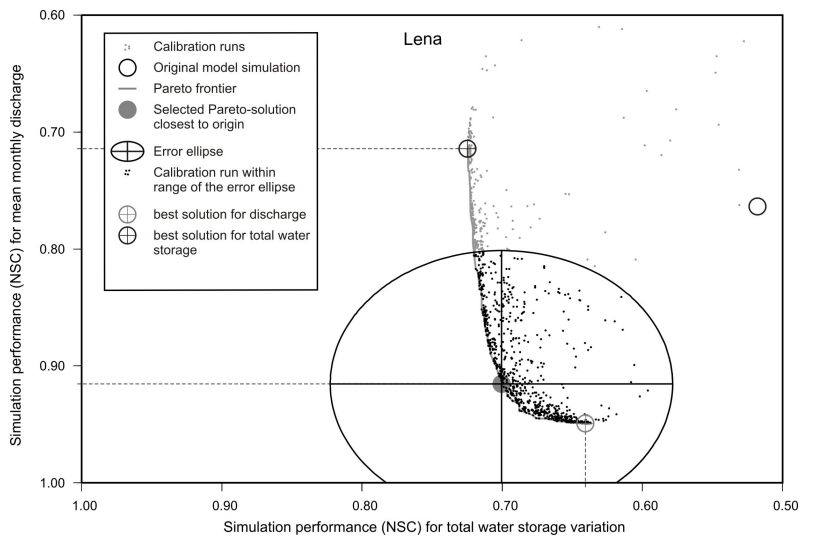

Fig. 4. Calibration results for the Lena river basin in terms of objective function values. Each point (gray and black) represents one model run. The Pareto optimal solutions form a frontier (gray solid line) toward the optimal model fit (lower left corner). The Pareto solution closest to the optimum (gray large dot) is selected as the optimal solution of the calibration providing a balanced improvement for both objectives and is used for further studies. Best solutions for the single objectives are located at the end of the Pareto frontier (crossed large dots). An uncertainty range for both objectives is indicated by an error ellipse around the selected Pareto solution from errors of the measured calibration data. The solutions lying in that range (black small dots) show a significant improvement in the calibrated model compared to the original model simulation (plain black circle).

\subsection{Uncertainty estimation due to observational errors}

The uncertainty of the calibration results due to errors in the calibration data is estimated for each river basin by the following procedure: 1) Selection of the calibration run with the Pareto solution closest to the optimum (see an example for the Lena river basin in Fig. 4). 2) Propagation of GRACE coefficient errors to basin-averaged estimates of TWSV as well as determination of the $20 \%$ discharge error. 3) Generation of 5000 normally-distributed samples within the estimated error ranges for the monthly data points of GRACE-based TWSV and monthly river discharge, respectively. The sample size was tested ahead of time and selected to provide stable statistical results. 4) Estimation of the objective functions (NSC) for each sample against simulated time series of the selected optimal solution for TWSV and discharge, respectively. 5) Determination of the NSC standard deviations for both objectives as the semi-axis for an error ellipse around the selected optimal solution. And 6) Selection of all calibration runs within the error ellipse (see Fig. 4 for the Lena basin).

The described approach determines all of the Pareto and non-Pareto solutions close to the selected optimum. These solutions cannot be evaluated to provide a better fit to the observations than the selected Pareto solution if observation errors are considered. The selected cluster of calibration solutions represents the total uncertainty of the calibration results regarding the observation errors. 


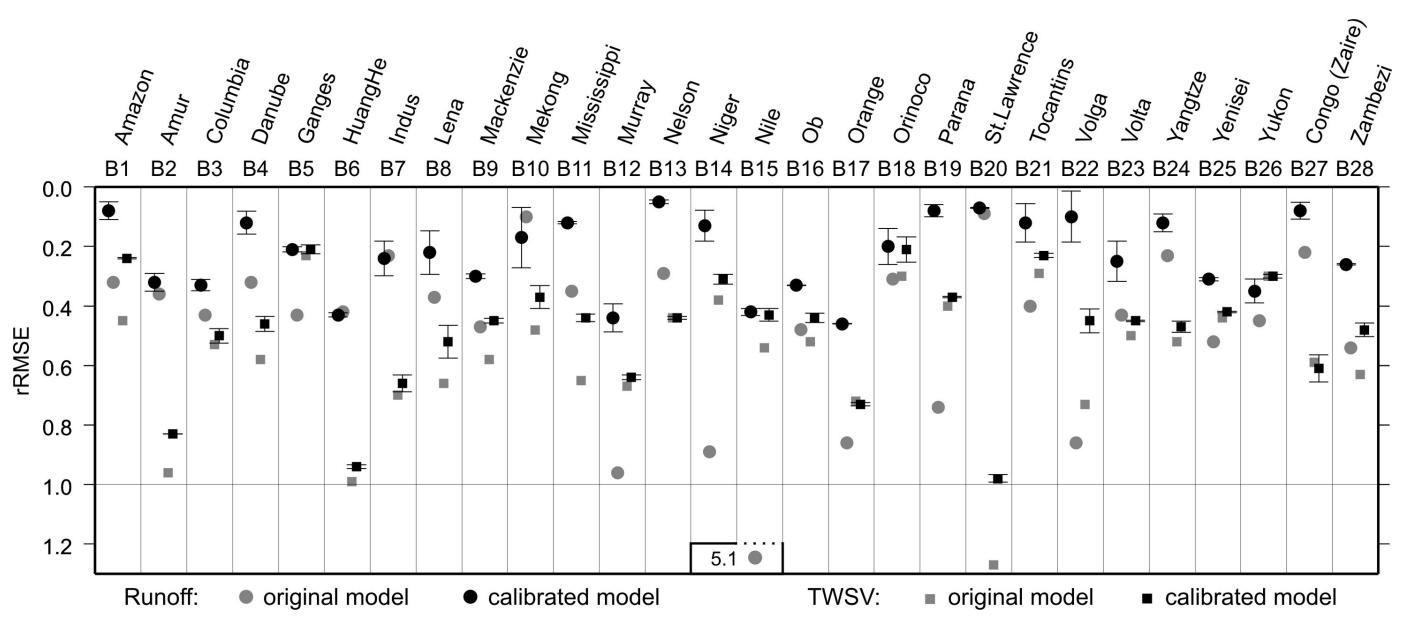

Fig. 5. Simulation performance for the 28 calibrated river basins in terms of relative root mean squared error (rRMSE) for river discharge (circles) and TWSV (squares) of the original (gray) and the calibrated model version (black) (see Table 4 for absolute values). Error bars are derived from GRACE and discharge measurement errors as described in Sect. 2.4.

\section{Results and discussion}

\subsection{Calibration results}

Detailed results for Lena basin (Fig. 4) demonstrate a typical objective function response that was found following the calibration of most river basins. A clear trade-off exists between both objective functions for TWSV and mean monthly discharge. The best solutions for the single objectives are located at the end of the Pareto frontier (crossed dots). Best results for a single objective, however, give an undesirable decrease in the accuracy for the other objective. The selected Pareto optimum (large gray dot) provides a balanced improvement between both objectives. The multi-objective calibration approach also decreases equifinality of the parameter sets since unacceptable parameter sets for any of the objectives are excluded by the multi-objective evaluation scheme. A more pronounced equifinality for simulating total water storage variations originates from the nature of total water storage data. GRACE provides no absolute values but only variations in water masses. Therefore, the same storage variations may be simulated by different model representations with different absolute amounts of water stored in the river basin. This is not the case for river discharge where both absolute values and variations are given by the observation data. Hence, a smaller number of model realisations provide good objective values for evaluation by discharge than by TWSV. The large ellipse around the selected Pareto optimum represents its uncertainty caused by measurement errors in the calibration data. Variations in parameter values or model output for model realisations within this range are not significant for the assumed observation data errors. Nevertheless, a significant improvement was achieved for both objective values relative to the original model in the analysis of the Lena basin.
An overview of the calibration results for all river basins is given in terms of the relative root mean squared error (RMSE, Fig. 5) against the discharge and GRACE measurements. The relative RMSE was computed from the RMSE of the time series of mean monthly discharge (circles) and TWSV (squares) against the root mean squared (RMS) values of the respective measurements. Absolute values for the signal RMS and model RMSE are presented in Table 4. Uncertainty ranges due to observational errors were transferred to RMSE and relative RMSE (error bars, Fig. 5). A comparison of the results for the calibrated model (black symbols) and the original model (gray symbols) indicate a successful calibration with significant improvements for both objectives for most of the basins. The highest relative improvements in TWSV simulations are provided (and respective RMSE improvements as height of a water column) for the Amazon (ca. $24 \mathrm{~mm} \approx 20 \%$ ), Danube $(8 \mathrm{~mm} \approx 13 \%)$, Lena $(4 \mathrm{~mm} \approx 13 \%)$, Mekong $(13 \mathrm{~mm} \approx 12 \%), \quad$ Mississippi $\quad(8 \mathrm{~mm} \approx 20 \%), \quad$ Volga $(13 \mathrm{~mm} \approx 27 \%)$, and Zambezi $(15 \mathrm{~mm} \approx 14 \%)$. In particular, mean monthly discharge simulations improved for the Amazon (with $110 \mathrm{~km}^{3} / \mathrm{month}$ decrease in $\mathrm{RMSE} \approx 23 \%)$, Danube $\left(4 \mathrm{~km}^{3} /\right.$ month $\left.\approx 24 \%\right)$, Niger $\left(14 \mathrm{~km}^{3} /\right.$ month $\left.\approx 78 \%\right)$, Tocantins $\left(10 \mathrm{~km}^{3} / \mathrm{month} \approx 28 \%\right)$, and Volga $\left(18 \mathrm{~km}^{3} / \mathrm{month} \approx 78 \%\right)$. Improvements were achieved for TWSV simulations only for the Huang $\mathrm{He}$, Indus and Mekong. The discharge accuracy is at the same level for the calibrated compared to the original model for the Huang $\mathrm{He}$ and Indus and the accuracy decreased slightly for Mekong. The discharge simulations of all three basins are within the measurement error bands. The Nelson, Orange, Yukon, and Congo (Zaire) exhibit an improvement in discharge simulations while the TWSV simulations are at the same performance level as they were in the original model. 


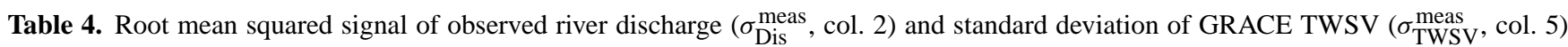
compared to the root mean squared error (RMSE) of the calibrated $\left(\epsilon^{\mathrm{cal}}\right.$, col. 3 and 6) and the original ( $\epsilon^{\mathrm{org}}$, col. 4 and 7$)$ model against respective observation data for all 28 river basins. Column 8 provides differences of RMSE values of TWSV from the calibrated and the original model for the validation period (January 2008-December 2008). Here, negative values indicate an improved simulation of the calibrated compared to the original model.

\begin{tabular}{|c|c|c|c|c|c|c|c|}
\hline $\begin{array}{l}\text { Basin } \\
\text { No. }\end{array}$ & $\begin{array}{c}\sigma_{\text {Dis }}^{\text {meas }} \\
{\left[\mathrm{km}^{3} / \mathrm{mth}\right]}\end{array}$ & $\begin{array}{c}\epsilon_{\text {Dis }}^{\text {cal }} \\
{\left[\mathrm{km}^{3} / \mathrm{mth}\right]}\end{array}$ & $\begin{array}{c}\epsilon_{\text {Dis }}^{\text {org }} \\
{\left[\mathrm{km}^{3} / \mathrm{mth}\right]}\end{array}$ & $\begin{array}{c}\sigma_{\text {TWSV }}^{\text {meas }} \\
{[\mathrm{mm}]}\end{array}$ & $\begin{array}{c}\epsilon_{\text {TWSV }}^{\mathrm{cal}} \\
{[\mathrm{mm}]}\end{array}$ & $\begin{array}{c}\epsilon_{\text {TWSV }}^{\text {org }} \\
\text { [mm] }\end{array}$ & $\begin{array}{c}\Delta \epsilon_{\text {TWSV }}^{2008}(\mathrm{cal}-\mathrm{org}) \\
{[\mathrm{mm}]}\end{array}$ \\
\hline B1 & 471 & 39 & 149 & 118 & 29 & 53 & -31 \\
\hline B2 & 31 & 10 & 11 & 30 & 25 & 29 & -2 \\
\hline B3 & 13 & 4 & 6 & 65 & 33 & 35 & -3 \\
\hline B4 & 17 & 2 & 6 & 61 & 28 & 36 & -7 \\
\hline B5 & 44 & 9 & 19 & 103 & 21 & 24 & 2 \\
\hline B6 & 4 & 2 & 2 & 26 & 25 & 26 & 0.4 \\
\hline B7 & 11 & 3 & 3 & 40 & 26 & 28 & 2 \\
\hline B8 & 64 & 14 & 24 & 31 & 16 & 20 & -10 \\
\hline B9 & 29 & 9 & 14 & 34 & 15 & 20 & -10 \\
\hline B10 & 34 & 6 & 3 & 113 & 42 & 54 & -14 \\
\hline B11 & 42 & 5 & 15 & 41 & 18 & 26 & -12 \\
\hline B12 & 0.8 & 0.4 & 0.8 & 24 & 15 & 16 & -0.1 \\
\hline B13 & 5.3 & 0.3 & 2 & 46 & 20 & 20 & -1 \\
\hline B14 & 18 & 2 & 16 & 76 & 23 & 29 & -5 \\
\hline B15 & 3 & 1 & 17 & 50 & 22 & 27 & -6 \\
\hline B16 & 43 & 15 & 21 & 46 & 20 & 23 & -5 \\
\hline B17 & 0.7 & 0.3 & 0.6 & 12 & 9 & 9 & -0.1 \\
\hline B18 & 98 & 20 & 31 & 168 & 36 & 50 & 18 \\
\hline B19 & 45 & 4 & 33 & 49 & 17 & 20 & -7 \\
\hline B20 & 20 & 1 & 2 & 39 & 38 & 50 & -19 \\
\hline B21 & 36 & 4 & 14 & 157 & 36 & 46 & -10 \\
\hline B22 & 23 & 2 & 20 & 48 & 22 & 35 & -7 \\
\hline B23 & 3 & 0.9 & 1 & 84 & 38 & 42 & -7 \\
\hline B24 & 80 & 10 & 18 & 36 & 17 & 19 & -3 \\
\hline B25 & 73 & 23 & 38 & 37 & 16 & 16 & -0.4 \\
\hline B26 & 21 & 8 & 10 & 65 & 20 & 20 & -5 \\
\hline B27 & 112 & 9 & 25 & 41 & 25 & 24 & -4 \\
\hline B28 & 9 & 2 & 5 & 107 & 52 & 67 & -25 \\
\hline
\end{tabular}

With the selected optimum parameter sets, WGHM simulations were repeated between January 2008December 2008 beyond the calibration period for validation against the GRACE-based TWSV. Table 4 shows that the improvement relative to the original model is similar to the calibration period for most of the river basins. For example, RMSE differences from the original model are promising for the Amazon $(31 \mathrm{~mm} \approx 26 \%)$, the Lena $(10 \mathrm{~mm} \approx 32 \%)$, Mackenzie $(10 \mathrm{~mm} \approx 29 \%)$, Mekong $(14 \mathrm{~mm} \approx 12 \%)$, St. Lawrence $(19 \mathrm{~mm} \approx 49 \%)$, and Zambezi $(25 \mathrm{~mm} \approx 23 \%)$. Only a slight improvement in the TWSV simulation is achieved in the validation period for the Murray, Nelson, Orange and Yenisei. A larger RMSE than for the original model was found for the Ganges, Huang He, Indus, Orinoco, Nelson, Orange, and Congo. This corresponds to the calibration failure of the latter three basins mentioned above.

\subsection{Simulation of seasonal TWSV}

The effects of model calibration on seasonal amplitudes and phases of TWSV are given in Fig. 6. For most basins, the amplitude was shifted toward the GRACE observations. The strongest improvements for the seasonal amplitude were achieved, e.g. for the Amazon, Mackenzie, Niger, Orinoco, and Zambezi. Reduced seasonal phase differences between GRACE and WGHM could be achieved by calibration for some basins, including the Amazon, Mississippi, $\mathrm{Ob}$ and Congo. Only phases could be corrected for the Columbia, Danube, Lena, Nelson, Parana, and Yenisei. There was no success in the calibration results for the Huang $\mathrm{He}$ in case of the seasonal signal. The phases differ strongly between GRACE and WGHM for the Amur and Orange but TWS does not exhibit a distinct seasonal signal in both basins (not shown). 


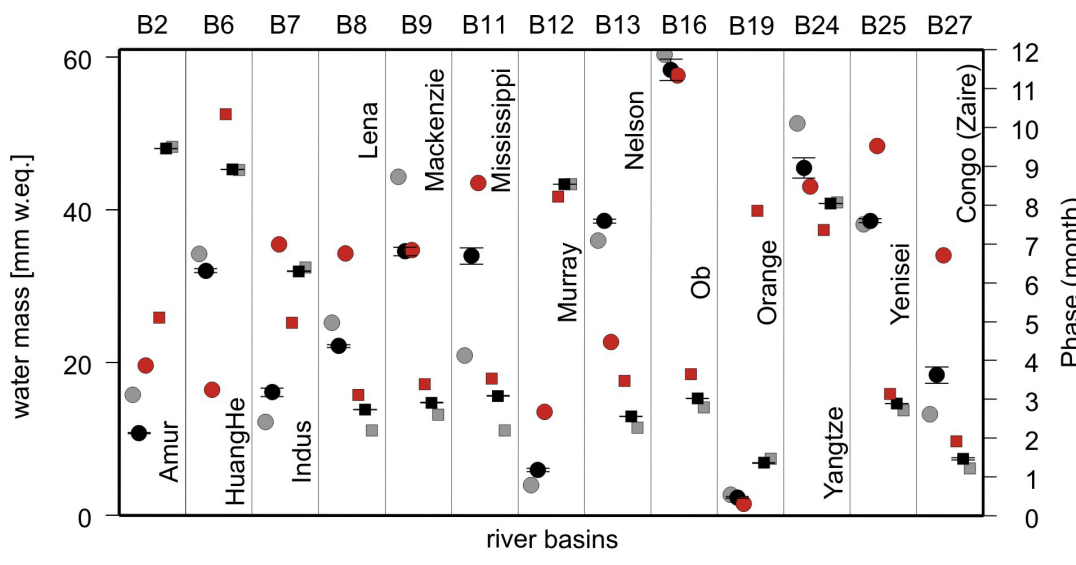

Seasonal TWSV:
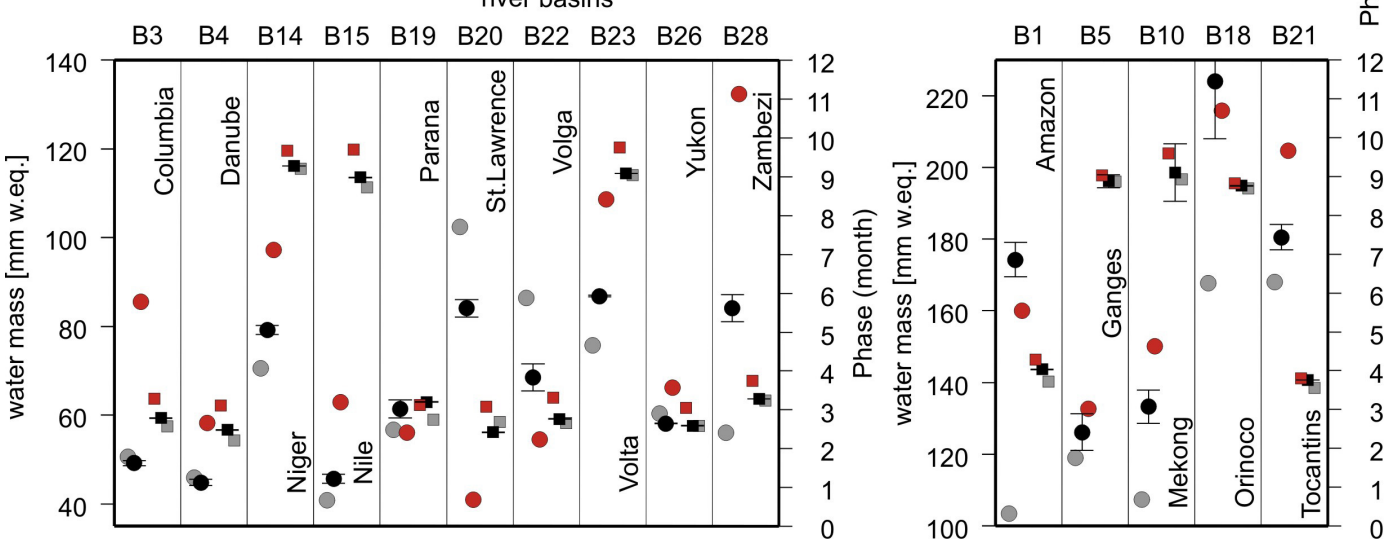

Fig. 6. Results for seasonal amplitude (circles) and phase (squares) of TWSV for the original (gray) and the calibrated model version (black) compared to GRACE (red). Error bars for TWSV amplitudes are derived from GRACE and discharge measurement errors as described in Sect. 2.4.

\subsection{Parameter values and single storage compartments}

A detailed analysis of parameter changes (Fig. 7) and their effects on single storage compartments (Fig. 8-11) is provided for seven river basins from different continents, climatic conditions, and with different calibration successes. Storage in lakes, floodplains, and wetlands (denoted surface water) is analysed separately from water in the river channel (denoted river storage) in the following sections.

AMAZON. The improved representation of TWSV simulations for the tropical Amazon after multi-criterial calibration is mainly due to a lower river flow velocity (SW-2) in the calibrated model version and a larger runoff coefficient (SW-1). The adjustment of both parameters is stable against calibration uncertainty from observation errors (Fig. 7a). The parameter changes cause a longer-lasting storage of more water in the river network that leads to larger and delayed seasonal amplitudes of TWS, which is in line with GRACE observations (Fig. 8a). Furthermore, inter-annual variations of TWS, such as the heavy drought that was experienced in the Amazon in 2005 (Zeng et al., 2008), are better represented with the calibrated model (Fig. 8a). A slightly increased soil water storage is due to the larger rooting depth (SL-1) in the recalibrated model. However, the rooting depth parameter is highly uncertain and it is not significant relative to the original model. This can be seen in the wide spread of parameter values for the Pareto solutions in Fig. 7a. The larger value for the parameter wetland depth (SW-4) has nearly no effect on the storage variability in lakes and wetlands despite the great importance of wetlands and floodplains for water storage in the Amazon (Papa et al., 2008). Surface water storage is mainly attributed to river channel storage in WGHM (Fig. 8a), although the large inundation areas are taken into account as model input. This might indicate structural model errors in representing surface water exchange processes between floodplains and the channel due to the conceptual model formulations and the cell-based simulation of surface water bodies in WGHM.

MississipPI. The Mississippi basin is located in varying climate zones ranging from cold to temperate (Fig. 1). Therefore, the Mississippi shows a more complex contribution of the individual storage compartments (Fig. 8b) than the Amazon. The most important change in TWSV after model calibration is due to a larger soil storage variability and a longer storage persistence in the early summer that is caused by a deeper rooting depth (SL-1). Secondly, a higher snow melting temperature (SN-2) causes an increased snow peak and delays melting by one month. The changes for snow 
and soil storage are supported by a lower radiation proportion absorbed by the surface, which leads to higher snow accumulation as well as a delayed snow melting. Compared to the original model, these parameter changes for the Mississippi are reliable considering the calibration uncertainty (Fig. 7d). An earlier seasonal peak of simulated TWS compared to GRACE data (see Fig. 8b) might be attributed to underestimated groundwater storage that is typically characterised by a later seasonal phase compared to near-surface storage. In fact, studies by Rodell et al. (2007) and Zaitchik et al. (2008) demonstrate a higher groundwater volume than was represented by WGHM. A change for groundwater was prevented by the missing sensitivity of the groundwater parameter for WGHM (B11 in Table 3), which might be due to the overlap with soil storage variations. The groundwater parameters should therefore be included in further calibration studies.

LENA. In the Lena basin, the seasonality of river water storage exhibits an opposite phase to total storage, which is dominated by snow storage variations. This makes a fit of the overall small TWSV amplitude (below $50 \mathrm{~mm}$ w.eq. on average) more difficult than for the two previous basins. Model improvements by calibration for this cold, high-latitude basin (Fig. 1) are mainly temporal. The phase of TWSV could be corrected (Fig. 6) based on changes in water accumulation in snow, the river, and soil (Fig. 9a). Due to a higher snow melting temperature (SN-2), snow accumulation lasts nearly one month longer and snow melting finally occurs later but more rapidly during April and May. The larger snow albedo (ER-3) decreases snow sublimation and supports the slightly larger variability in snow storage. In line with later and faster snow melting in the spring, water storage dynamics in the river network change accordingly. A larger and later monthly runoff peak also corresponds to the river discharge measurements and is better represented by the calibrated model (see embedded graph in Fig. 9a). Changes in the soil storage dynamics due to calibration are of minor importance in the Lena basin. In general, they are characterised by slightly larger seasonal variations with a later phase commensurate to the snow dynamics but also to overall lower evapotranspiration rates caused by smaller radiation proportion (ER-1) and PTcoefficient (ER-5) parameters.

DANUBE. Similar to Lena, mainly a phase correction of TWSV was achieved by calibration (Fig. 6) for the cold and partly temperate (Fig. 1) Danube basin. This resulted in a smaller RMSE of TWSV time series (Fig. 5). While the seasonal amplitude was not changed, a better fit for extreme events such as heat waves or floods (Andersen et al., 2005; Seitz et al., 2008) is visible in the time series for the autumns of 2003, 2005, and 2006, as well as for the water mass maxima in 2004 and 2006 (Fig. 9b). In the calibrated model, snow is melting faster due to a higher snow melting temperature, hence reducing the snow storage volume. The released water is mainly stored in the soil that has an increased storage capacity due to a larger root depth parameter
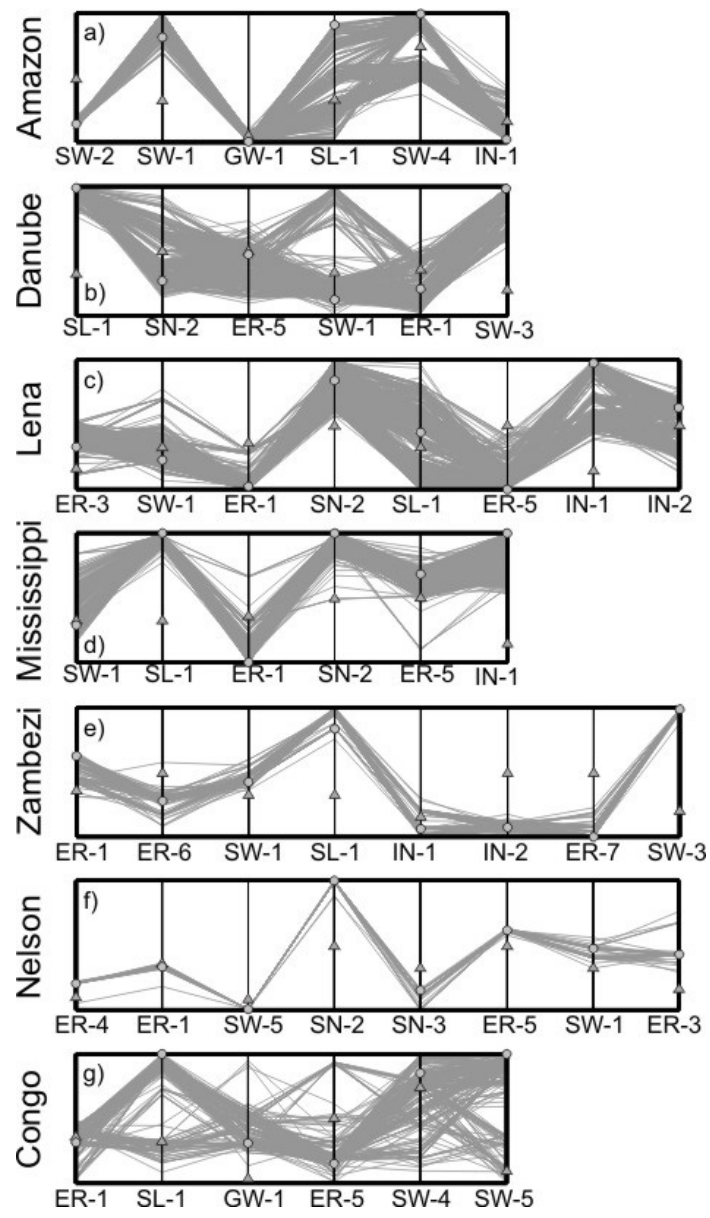

Fig. 7. Normalised parameters for exemplary river basins (a-g). Parameter sets are shown for the selected optimum (circular symbols), the original model version (triangles), and all calibration runs within the uncertainty range (gray solid lines) due to observational errors.

after calibration. Additionally, river water is reallocated to the soil where it can remain for longer periods than in the quickly draining river network during the spring season. The smaller river discharge in spring is confirmed by observations (not shown here, due to limited space) resulting in a smaller RMSE for the mean monthly discharge (Fig. 5). Groundwater storage variations slightly decreased and were delayed in the Danube basin.

ZAMBEZI. Increased storage variations in the hottemperate and partly dry Zambezi basin (Fig. 1) are due to larger soil, groundwater, and surface water storage amplitudes (Fig. 10a). The largely corrected seasonal variability of TWSV (Fig. 6) in the calibrated model mainly originates from less evapotranspiration of surface and soil water and is controlled by a smaller PT-coefficient (ER-6) and a smaller maximum potential evapotranspiration (ER-7). WGHM contains only one soil layer, so it might be exhausted too quickly by evapotranspiration in the dry Zambezi region instead of being stored in deeper soil layers. This is supported by the 


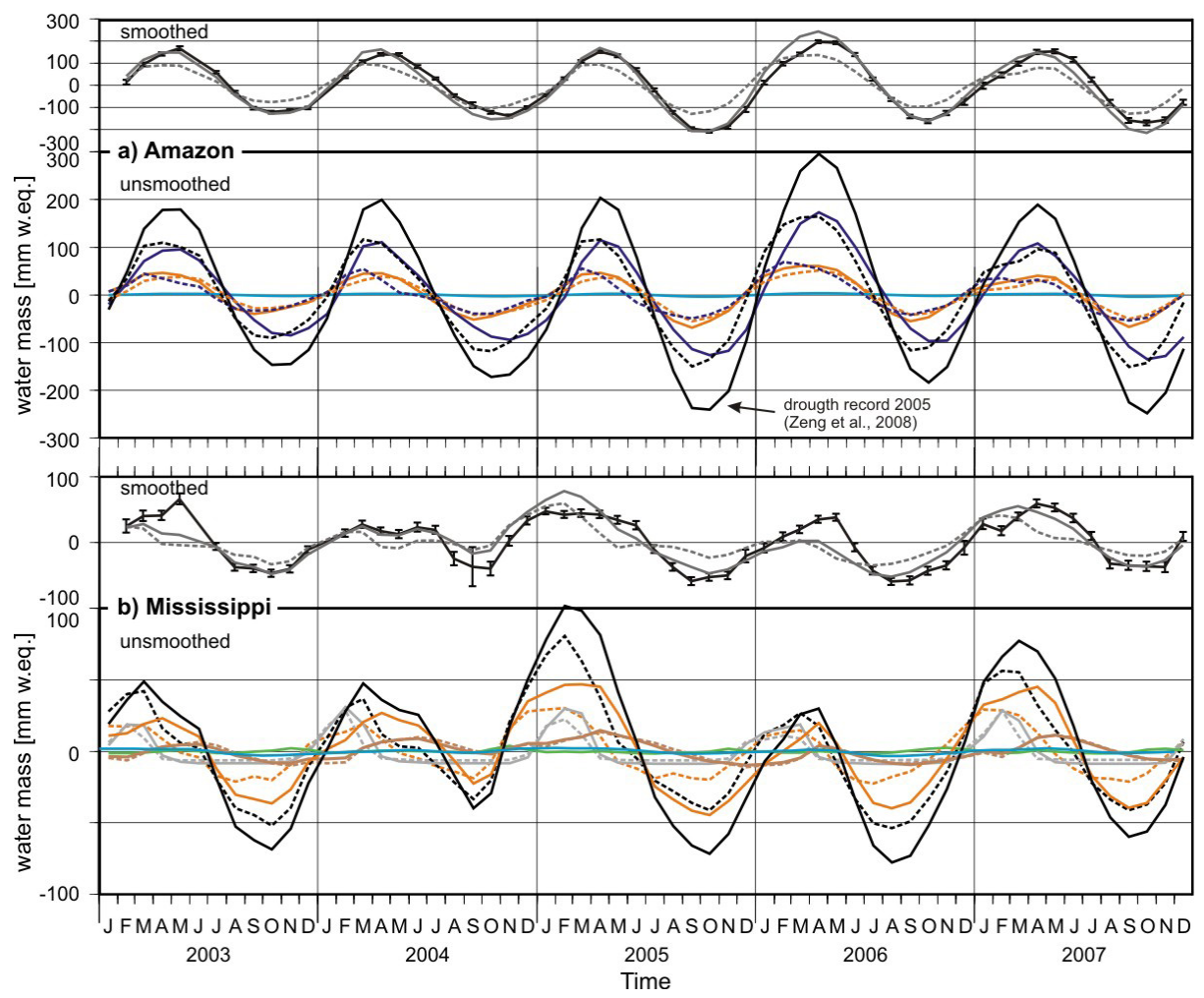

Fig. 8. Basin-averaged time series of single storage compartments from the calibrated and the original model version (unsmoothed, below) as well as smoothed total storage from both model versions and GRACE (smoothed, above) for (a) the Amazon and (b) the Mississippi basins. See Fig. 11 for the legend.

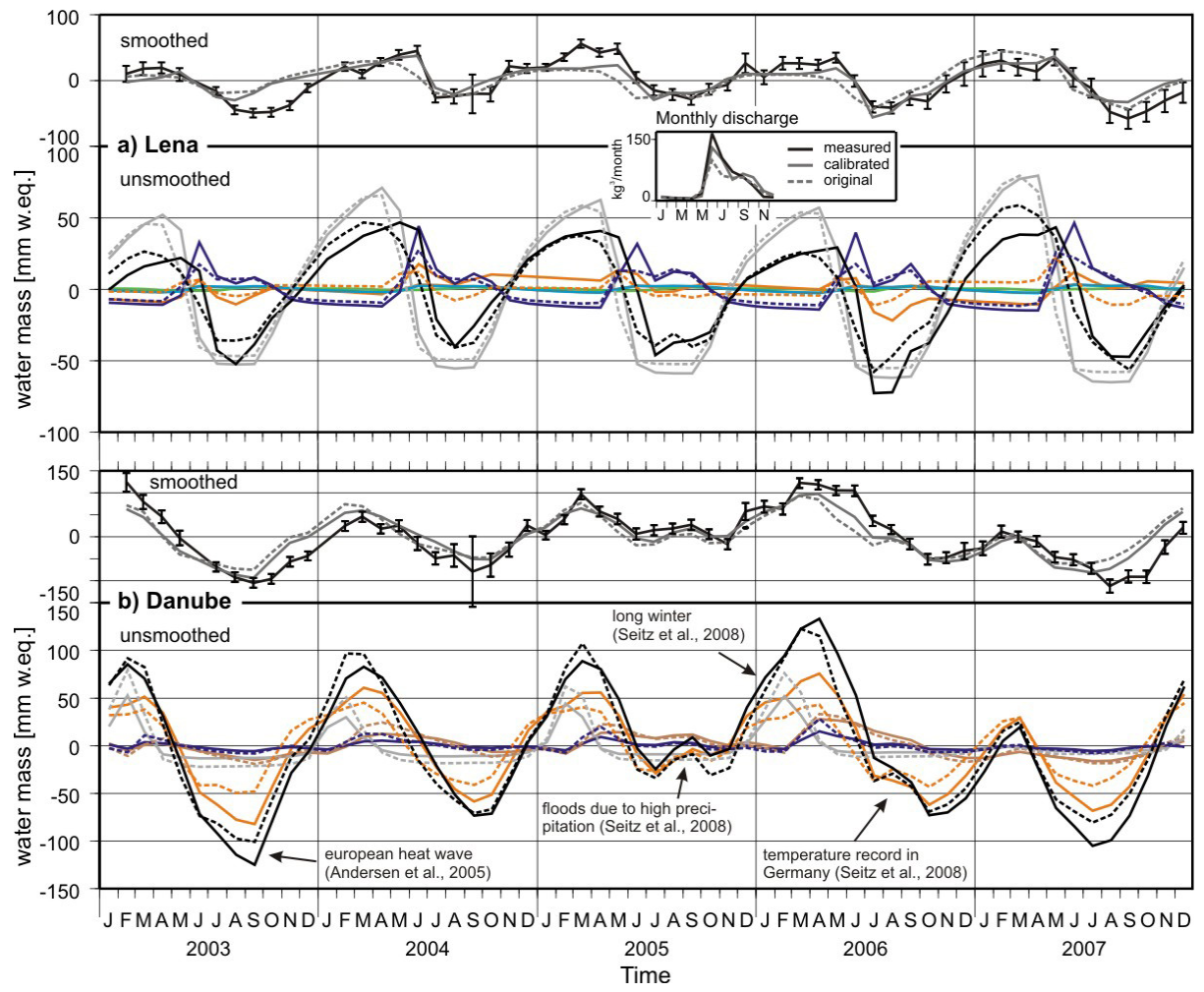

Fig. 9. Same as Fig. 8 but for (a) the Lena and (b) the Danube basins. 


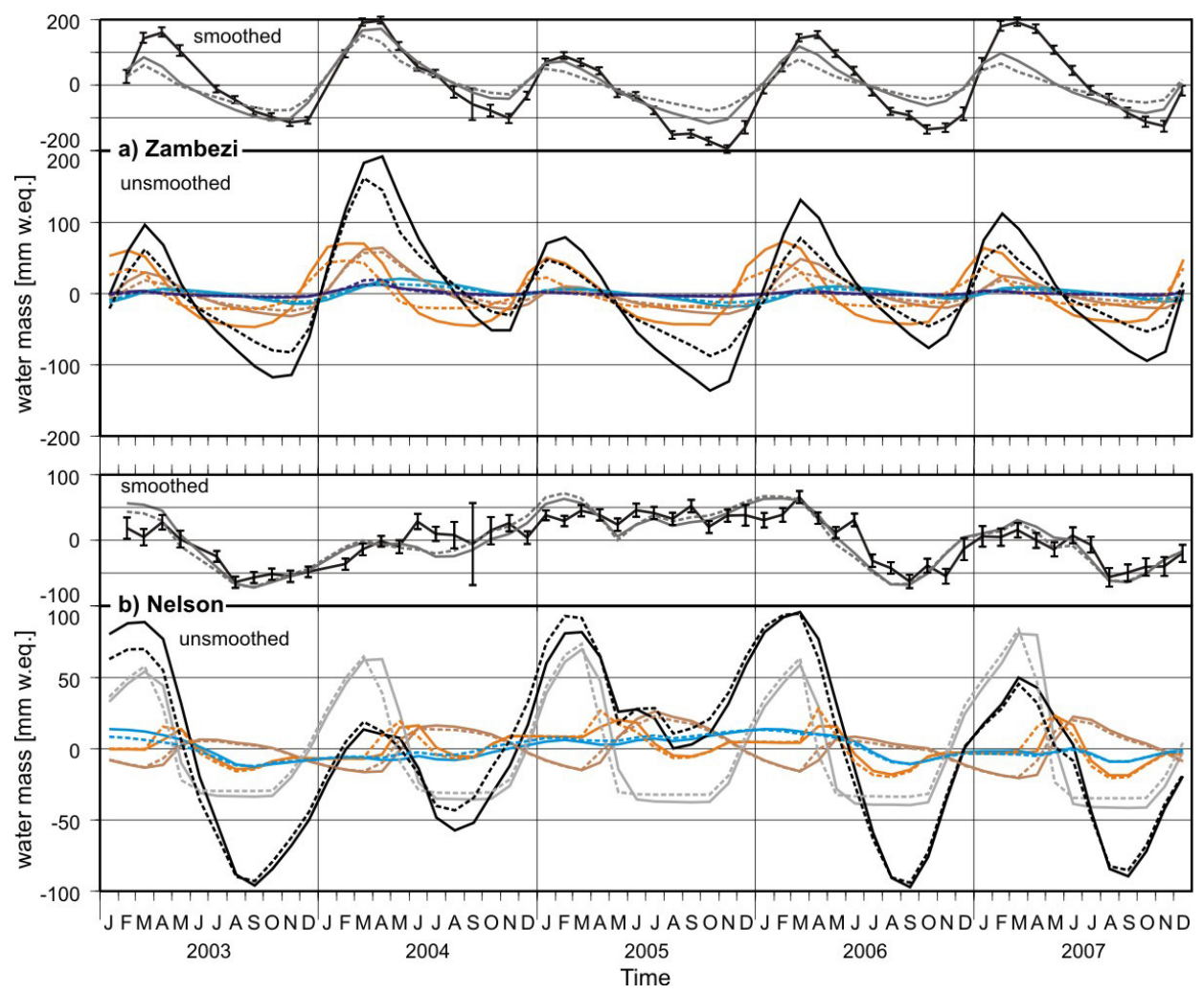

Fig. 10. Same as Fig. 8 but for (a) the Zambezi and (b) the Nelson basins.

observation of increased groundwater volume, which confirms the high relevance of water exchange with deeper soil zones for the Zambezi basin (Winsemius et al., 2006a). Surface water volume changes in wetlands increase after calibration and result in longer residence times of water in the Zambezi basin. The importance of this storage mechanism in the Zambezi basin was also noted by Winsemius et al. (2006a).

NELSON. The seasonality of snow and groundwater storage exhibits a marked anti-phase in the Nelson basin according to the WGHM simulation results (Fig. 10b). This decreases model sensitivity for TWS variations and makes an effective calibration of the individual storage components difficult, since many combinations of different snow and groundwater states can lead to an equally good fit of simulated to GRACE-based TWSV. In addition, the required smoothing of GRACE data has a huge effect on overall water storage dynamics for this basin (Fig. 10b). Major seasonal signals are smoothed, but the remaining TWSV time series correspond reasonably well between GRACE and WGHM. Comparatively small changes occur by model re-calibration relative to the original model.

CONGO. TWSV in the Congo (Zaire) basin is dominated by inter-annual patterns such as the water loss that occurred between 2003 and 2005 (Crowley et al., 2006). As assumed by Crowley et al. (2006), the loss is not secular and the storage is filled up again during 2006 and 2007 (Fig. 11). Although the calibrated WGHM exhibits an improved simulation for the seasonal amplitude and phase of the Congo basin (Fig. 6), the simulated inter-annual variability of basin-average TWS is still different from GRACE, e.g. a too large negative anomaly in 2005. Also, RMSE values did not improve after calibration (Table 4). The inter-annual variations in TWS mainly derive from soil and groundwater storage (Fig. 11). For the calibrated model, a larger seasonal variability in soil storage causes a slightly delayed phase of storage variability. This delay appears to be compensated by a negative phase shift in groundwater. As a result, the faster outflow of the groundwater due to a larger outflow coefficient GW-1 causes a smaller groundwater volume and decreases the inter-annual variation of groundwater storage in the calibrated model.

Three out of the four basins (Nelson, Orange, Congo) that have unsuccessful calibrations for TWS exhibit strong inter-annual variations (see Fig. 10b for Nelson and Fig. 11 Congo). The inter-annual variations are visible in GRACE as well, but the short period of five years used here might impair an effective calibration of inter-annual changes in total storage variability and its components. Furthermore, a large trade-off occurs for the Pareto solutions between simulation performance of river discharge simulation and TWS for Congo, Nelson, and Orange (not shown). Therefore, calibration difficulties within these basins might also be due to the use of mean monthly discharge values, which neglect interannual or secular variations during the calibration period. An 


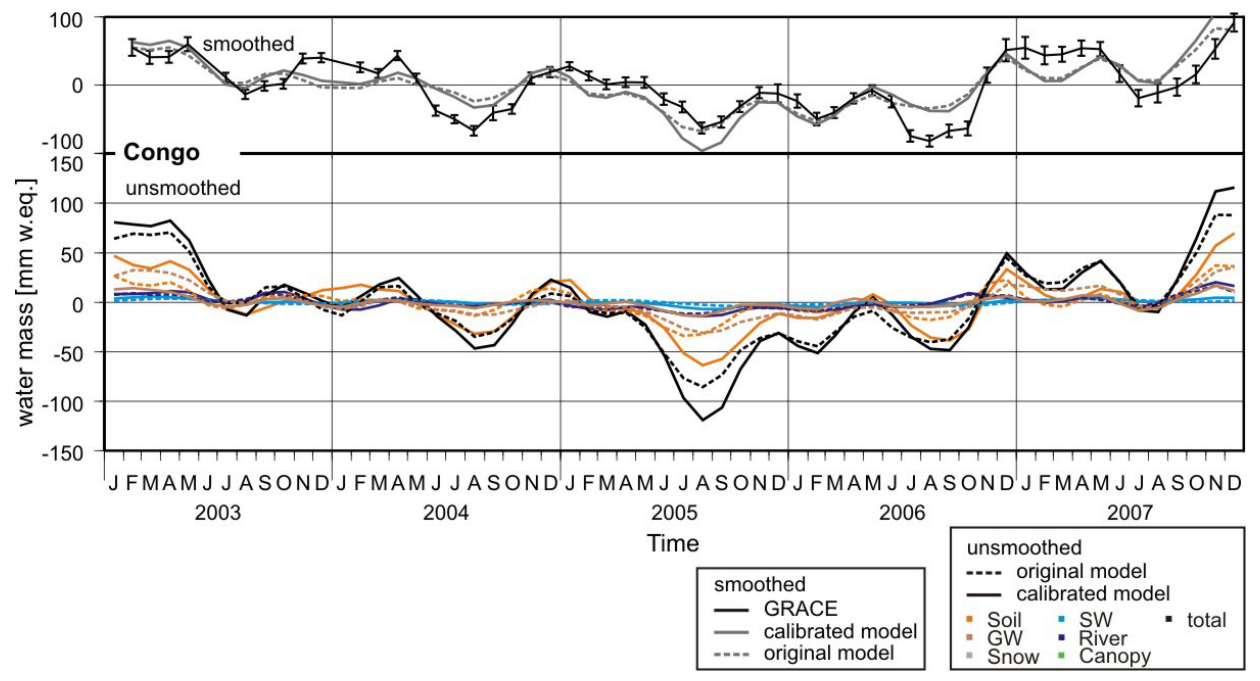

Fig. 11. Same as Fig. 8 but for the Congo basin.

additional drawback for the Congo is that the available discharge data for this basin are only from 1954-1983.

The water mass variations of the Orange basin, which also exhibit inter-annual variations (not shown), are smaller than $12 \mathrm{~mm}$ of a water column (see Table 4, Fig. 6) and are below GRACE data accuracy for some months. While inter-annual variations are not relevant for the Yukon basin, a clear antiphase between snow and groundwater storage as well as soil storage causes a small model sensitivity for TWS variations, similar to Nelson.

\subsection{Global analysis}

A global analysis of simulated TWSV for the calibrated model (see spatial distribution in Fig. 12 and variability of basin averages in Table 5) shows that its variability increased for most river basins compared to the original model. On the global average (last row of Table 5), TWS variability increased by $7 \mathrm{~mm}$ w.eq., which is mainly due to larger variations in soil, river, and surface water storage. Most variability is gained within the tropical and temperate regions, such as the Amazon (total $60 \mathrm{~mm}$ for the basin average), Congo (9 mm), Niger (14 mm), Mekong (35 mm), and the Mississippi $(14 \mathrm{~mm})$. A spatial redistribution between sub-regions for some of these basins is visible in Fig. 12, e.g. Ganges and Parana. A smaller total water budget appears only for the basins in cold regions including the Mackenzie, St. Lawrence, Volga, and Yangtze (Table 5). Some further cold regions such as the Lena or Ob exhibit an unchanged water budget. This comparison shows that TWS variability in the original WGHM was mainly underestimated in tropical and temperate regions but overestimated in cold regions, similar to the seasonal components (Fig. 6).

For the individual basins and storages, largest differences from the original model occur within soil storage, mainly for tropical and temperate regions such as the Mekong,
Mississippi, Orinoco, Volta, or Zambezi basins. This is visible by area distributed TWSV differences compared to the original model (the lower section of Fig. 12) and is reflected in the basin averages (Table 5). Soil has the highest seasonal capacity to store water and contributes the most to the gravity signal discovered by GRACE, which is usually dominated by seasonal features. Linear structures in the spatial distribution of TWSV differences compared to the original model are mainly due to changes in river storage, the second greatest contributor to changes for the basin averages (Table 5). Very large increases in river water volumes occur in the rainy tropical regions of Amazon the, Mekong, and Orinoco, where a slow discharge in the river network causes a longer maintenance of river water in the basin (see analysis for Amazon in Sect. 3.3 above). In contrast, a decrease in river water volume is found in temperate and dry regions. Snow storage increases for regions in cold climate zones, such as the Columbia, Ob, and Yenisei basins. Snow storage decreases in cold climates that have warm summers, such as the St. Lawrence, Volga, and Danube. In these transition zones, less snow precipitation might be due to global climate warming, which is relevant for the calibration period but was not incorporated in the calibration of the original model.

Simulated groundwater storage changes decreased on a global scale. A large decrease in groundwater variations occurred for regions that have a distinct dry season (Ganges, Niger, Nile) and for some cold regions (St. Lawrence, Volga). Groundwater seasonality is usually delayed compared to soil and surface storage since soil transfer processes temporarily filter groundwater recharge. As seen from the seasonal phase shift between GRACE and WGHM, water often drains too quickly from river basins compared to GRACE, even in the calibrated model version. This might be explained by a too little groundwater recharge and volume in WGHM (Zambezi or Mississippi). Furthermore, the sensitivity of the model to changes in groundwater storage might be superimposed 
Table 5. Variability of unfiltered and basin-averaged continental TWSV simulations from the calibrated WGHM version for total storage and single compartments: $\sigma^{\text {cal }}$ (storage) (TS: total storage, SL: soil, GW: groundwater, SN: snow, R: river, SW: surface water, C: canopy). Every other line provides deviations of storage variability to the original model: $\Delta \sigma_{\text {storage }}=\sigma^{\text {cal }}$ (storage) $-\sigma^{\text {org }}$ (storage).

\begin{tabular}{|c|c|c|c|c|c|c|c|c|c|c|c|c|c|c|}
\hline Basin & $\sigma^{\mathrm{cal}}(\mathrm{TS})$ & $\Delta \sigma_{\mathrm{TS}}$ & $\sigma^{\mathrm{cal}}(\mathrm{SL})$ & $\Delta \sigma_{\mathrm{SL}}$ & $\sigma^{\mathrm{cal}}(\mathrm{GW})$ & $\Delta \sigma_{\mathrm{GW}}$ & $\sigma^{\mathrm{cal}}(\mathrm{SN})$ & $\Delta \sigma_{\mathrm{SN}}$ & $\sigma^{\mathrm{cal}}(\mathrm{R})$ & $\Delta \sigma_{\mathrm{R}}$ & $\sigma^{\mathrm{cal}}(\mathrm{SW})$ & $\Delta \sigma_{\mathrm{SW}}$ & $\sigma^{\mathrm{cal}}(\mathrm{C})$ & $\Delta \sigma_{\mathrm{C}}$ \\
\hline B1 & 150 & +60 & 37 & +8 & 25.7 & +0.4 & 0.1 & +0.0 & 82.9 & +49.6 & 2.1 & +0.8 & 0.0 & +0.0 \\
\hline B2 & 20 & +3 & 10 & +3 & 7.8 & -0.4 & 21.0 & +1.7 & 5.0 & +0.2 & 1.4 & +0.2 & 0.5 & +0.3 \\
\hline B3 & 55 & -1 & 12 & -7 & 4.4 & -0.6 & 40.2 & +6.1 & 3.5 & +0.1 & 1.7 & -0.2 & 0.2 & +0.0 \\
\hline B4 & 64 & +4 & 43 & 13 & 10.6 & -2.2 & 16.0 & -9.4 & 4.1 & -3.0 & 1.4 & +0.9 & 0.4 & +0.0 \\
\hline B5 & 90 & +7 & 17 & -8 & 21.0 & -5.6 & 1.8 & +0.3 & 20.1 & +3.6 & 10.6 & +4.2 & 0.1 & +0.1 \\
\hline B6 & 18 & -2 & 9 & +1 & 5.9 & -1.4 & 0.3 & +0.0 & 2.7 & -0.6 & 0.3 & -0.2 & 0.1 & +0.1 \\
\hline B7 & 28 & +4 & 7 & +1 & 4.8 & +0.7 & 24.6 & +3.4 & 6.4 & +0.2 & 1.0 & +0.4 & 0.0 & +0.0 \\
\hline B8 & 32 & +0 & 8 & +2 & 1.7 & +0.2 & 47.9 & +2.8 & 15.2 & +4.7 & 1.8 & +0.1 & 0.8 & +0.5 \\
\hline B9 & 44 & -8 & 7 & -1 & 7.8 & +0.5 & 50.7 & +0.1 & 6.9 & +3.5 & 1.5 & -1.3 & 0.3 & +0.0 \\
\hline B10 & 129 & +36 & 54 & +22 & 33.5 & +0.6 & 0.3 & +0.0 & 37.1 & +11.2 & 3.1 & +0.7 & 0.1 & +0.1 \\
\hline B11 & 48 & +14 & 27 & +11 & 6.3 & -0.4 & 12.1 & +2.6 & 3.4 & -0.6 & 1.9 & +0.0 & 1.1 & +0.9 \\
\hline B12 & 17 & +3 & 9 & +1 & 2.1 & -0.6 & 0.0 & +0.0 & 0.6 & +0.4 & 2.4 & +0.7 & 0.0 & -0.1 \\
\hline B13 & 57 & +2 & 10 & -1 & 12.2 & +1.2 & 39.8 & +2.4 & 0.5 & -0.2 & 7.7 & +0.5 & 0.2 & +0.0 \\
\hline B14 & 58 & +14 & 26 & +12 & 14.8 & -4.6 & 0.0 & +0.0 & 11.1 & +4.2 & 3.2 & -0.2 & 2.6 & +2.6 \\
\hline B15 & 35 & +2 & 21 & +8 & 1.6 & -5.3 & 0.0 & +0.0 & 9.7 & +1.2 & 3.5 & +0.3 & 0.0 & +0.0 \\
\hline B16 & 61 & +0 & 14 & -2 & 14.6 & +2.2 & 67.5 & +9.3 & 5.3 & +0.4 & 1.5 & -0.7 & 0.3 & +0.0 \\
\hline B17 & 6 & -1 & 3 & -1 & 2.3 & -0.3 & 0.0 & +0.0 & 0.5 & -0.3 & 0.4 & -0.1 & 0.3 & +0.3 \\
\hline B18 & 169 & +51 & 57 & +18 & 35.8 & +1.7 & 0.0 & +0.0 & 54.6 & +26.0 & 7.6 & +1.3 & 0.1 & +0.0 \\
\hline B19 & 59 & +1 & 22 & +6 & 19.3 & -0.8 & 0.0 & +0.0 & 5.1 & -10.3 & 5.6 & +2.4 & 0.1 & +0.0 \\
\hline B20 & 78 & -20 & 15 & -5 & 9.8 & -4.9 & 43.4 & -21.4 & 1.2 & -1.4 & 9.2 & -0.3 & 0.6 & +0.3 \\
\hline B21 & 145 & +18 & 39 & +17 & 43.0 & +0.8 & 0.0 & +0.0 & 16.0 & -9.4 & 13.1 & +2.3 & 0.3 & +0.3 \\
\hline B22 & 68 & -16 & 33 & +8 & 11.9 & -2.6 & 56.0 & -15.1 & 11.5 & -5.4 & 1.7 & +0.6 & 0.3 & +0.0 \\
\hline B23 & 80 & +26 & 49 & +28 & 19.2 & +1.9 & 0.0 & +0.0 & 2.5 & -0.4 & 4.6 & -1.8 & 1.0 & +1.0 \\
\hline B24 & 30 & -5 & 4 & -2 & 13.0 & +1.2 & 1.2 & +0.5 & 12.3 & -3.4 & 0.7 & +0.0 & 0.3 & +0.0 \\
\hline B25 & 41 & +2 & 9 & +1 & 6.8 & +1.3 & 56.0 & +7.5 & 9.1 & +3.9 & 1.9 & +0.5 & 0.3 & +0.0 \\
\hline B26 & 52 & -3 & 7 & +0 & 3.4 & +0.3 & 57.6 & +0.0 & 8.8 & +1.1 & 2.9 & +0.5 & 0.2 & +0.0 \\
\hline B27 & 47 & +9 & 26 & +12 & 6.3 & -8.8 & 0.0 & +0.0 & 7.3 & +1.2 & 2.8 & +0.6 & 0.0 & +0.0 \\
\hline B28 & 80 & +26 & 41 & +20 & 23.3 & +5.3 & 0.0 & +0.0 & 3.6 & -0.7 & 9.1 & +2.6 & 0.0 & +0.0 \\
\hline global & 66 & +7 & 24 & +3 & 15.4 & -0.6 & 20.5 & +0.2 & 9.4 & +3.3 & 13.2 & +2.7 & 0.2 & +0.1 \\
\hline
\end{tabular}

by the soil storage with a different seasonal phase. Therefore, future calibrations against GRACE data should include groundwater timing and volume parameters for each river basin.

Calibration results are also influenced by errors and uncertainties in climate data. Fiedler and Döll (2007) analysed those influences on WGHM model output and could show that uncertainties from climate input are smaller than differences to GRACE for WGHM output.

\section{Summary and conclusions}

A consistent and globally-improved simulation of continental water storage variations was achieved in this study by taking into account the following key points in a multiobjective calibration framework with GRACE water storage data: 1) Consistency of GRACE and model TWSV data by representing the most important storage compartments in the WGHM model (soil, snow, canopy, surface water, and groundwater). 2) Multi-objective calibration by absolute values of river discharge and relative values of TWS variations. 3) Basin-specific calibration of the dominant processes by varying the most sensitive model parameters. 4) Consistency of the observables and model state variables (equal spatial scale) by identical smoothing of GRACE and model data, as well as the application of the optimal filter method for each river basin. 5) Consideration of measurement errors in an uncertainty analysis of the calibration results.

The multi-objective calibration of WGHM led to improved simulation results, particularly for seasonal amplitudes and phases of both TWS variations and river discharge for most of the 28 calibrated river basins. TWS variability was largely increased for tropical regions in the calibrated model. A better representation of TWS variability in the calibrated model was corroborated by reasonable changes in simulated water storage in single storage compartments for seven river basins from different continents and diverse climatic regions. Additionally, possible model structural errors were uncovered by the calibration, such as wetland volumes that are too low in the Amazon and the Mississippi basin.

Model structure errors might complicate the calibration of WGHM with GRACE TWSV. However, limited spatial resolution or regionally varying accuracy (Winsemius et al., 2006b) of the GRACE data, as well as different smoothing effects between GRACE and modelled data, might also affect the calibration performance. GRACE errors and uncertainties are still an important object of research and depend on global model estimates for validation and error reduction. 

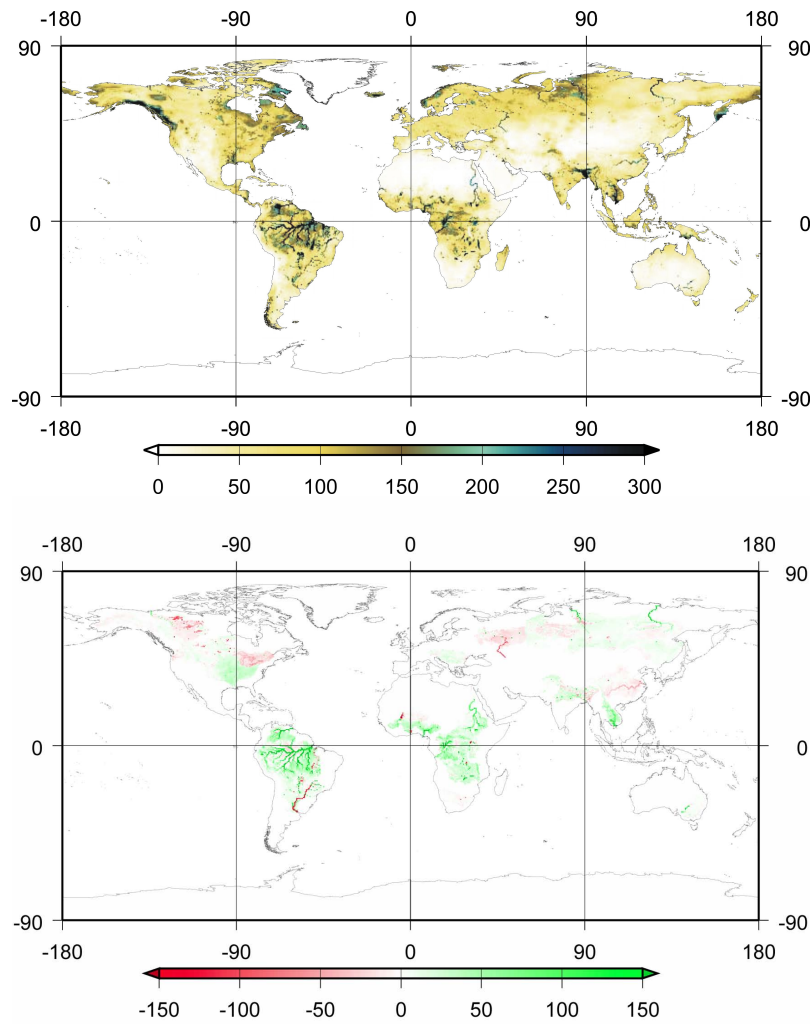

Fig. 12. Global distribution of total storage variability of the calibrated WGHM (above) and its deviations to the original model version (below). Negative values below indicate decreased and positive values increased variability. Units are in mm of water column.

This will restrict the independence of observation data and model re-calibrations but also emphasises that the improvement of large-scale hydrological models and the improvement of GRACE water mass estimates must be considered as an iterative process.

For some basins, errors or limitations in the calibration data restrict calibration success. The integrative nature of GRACE TWS data, their limited spatial resolution, and the lack of absolute water storage values imply that calibrating a hydrological model with GRACE data leaves the calibration results with a considerable degree of parameter equifinality. Considering the complex interaction between single storage components and the inability to separate these storages with the integrative TWSV data, GRACE data alone are not adequate to calibrate water storage state variables in large-scale hydrological models. Progress in remote sensing techniques for individual storages such as snow storage (e.g. by MODIS, Parajka and Blöschl, 2008), surface water (Papa et al., 2008), or soil moisture from the upcoming satellite missions SMOS and SMAP are applicable for tuning or validating large scalehydrological models with more than one or two objectives. An update of global river discharge data sets to the GRACE mission period is another urgent need for further progress.
Due to the large diversity of processes in different regions of manifold climatic conditions, global hydrological modelling is a challenging task. The present study expands experiences in the representation of hydrological processes to a global scale with a particular emphasis on water storage dynamics. The continuation of similar studies is further motivated by the steadily improved accuracy of GRACE solutions and the future prospect of a GRACE follow-on mission. Longer time series of gravity data will in particular allow focusing on hydrological extremes, inter-annual variations, and secular trends in both observations and modelling capabilities.

Acknowledgements. We acknowledge J. Alcamo and P. Döll for providing the WGHM model code. The German Ministry of Education and Research (BMBF) supported these investigations within the geoscientific R+D programme GEOTECHNOLOGIEN, "Erfassung des Systems Erde aus dem Weltraum". The authors also want to thank Ross Woods for productive discussions about the calibration analysis methods.

Edited by: J. Liu

\section{References}

Alcamo, J., Döll, P., Henrichs, T., Kaspar, F., Lehner, B., Rösch, T., and Siebert, S.: Development and testing of the WaterGAP 2 global model of water use and availability, Hydrolog. Sci. J., 48, 317-338, 2003.

Andersen, O. B., Seneviratne, S. I., Hinderer, J., and Viterbo, P.: GRACE-derived terrestrial water storage depletion associated with the 2003 European heat wave, Geophys. Res. Lett., 32, L18405, doi:10.1029/2005GL023574, 2005.

Beven, K. and Binley, A.: The future of distributed models: Model calibration and uncertainty prediction, Hydrol. Process., 6, 279 298, 1992.

Crowley, J. W., Mitrovica, J. X., Richard, C. B., Tamisiea, M. E., and Davis, J. L.: Land water storage within the Congo Basin inferred from GRACE satellite gravity data, Geophys. Res. Lett., 33, L19402, doi:10.1029/2006GL027070, 2006.

Dirmeyer, P. A., Gao, X., Zhao, M., Guo, Z., Oki, T., and Hanasaki, N.: GSWP-2: Multimodel Analysis and Implications for Our Perception of the Land Surface, B. Am. Meteorol. Soc., 87, 1381-1397, 2006.

Döll, P. and Fiedler, K.: Global-scale modeling of groundwater recharge, Hydrol. Earth Syst. Sc., 12, 863-885, 2008.

Döll, P. and Lehner, B.: Validation of a new global 30-min drainage direction map, J. Hydrol., 258, 214-231, 2002.

Döll, P., Kaspar, F., and Lehner, B.: A global hydrological model for deriving water availability indicators: model tuning and validation, J. Hydrol., 270, 105-134, 2003.

Duan, Q., Gupta, H. V., Sorooshian, S., Rousseau, A. N., and Turcotte, R.: Calibration of watershed models, American Geophysical Union, Washington DC, 89-104, 2003. 
Fenicia, F., Savenije, H. H. G., Matgen, P., and Pfister, L.: Understanding catchment behavior through stepwise model concept improvement, Water Resour. Res., 44, W01402, doi:10.1029/2006WR005563, 2008.

Fiedler, K. and Döll, P.: Global modelling of continental water storage changes - sensitivity to different climate data sets, Adv. Goesci., 11, 63-68, 2007.

Flechtner, F.: GRACE Science Data System Monthly Report, Feb. 2009, Tech. rep., http://isdc.gfz-potsdam.de/, 2009.

Gulden, L. E., Rosero, E., Yang, Z.-L., Rodell, M., Jackson, C. S., Niu, G.-Y., Yeh, P. J. F., and Famiglietti, J.: Improving landsurface model hydrology: Is an explicit aquifer model better than a deeper soil profile?, Geophys. Res. Lett., 34, L09402, doi:10.1029/2007GL029804, 2007.

Güntner, A.: Improvement of global hydrological models using GRACE data, Surv. Geophys., 29, 375-397, 2009.

Güntner, A., Stuck, J., Werth, S., Döll, P., Verzano, K., and Merz, B.: A global analysis of temporal and spatial variations in continental water storage, Water Resour. Res., 43, W05416, doi:10.1029/2006WR005247, 2007.

Gupta, H. V., Sorooshian, S., and Yapo, P. O.: Toward improved calibration of hydrologic models: Multiple and noncommensurable measures of information, Water Resour. Res., 34, 751-763, 1998.

Gupta, H. V., Beven, K. J., and Wagener, T.: Model Calibration and Uncertainty Estimation, in: Encyclopedia of Hydrological Sciences, edited by: Anderson, M., Wiley, Chichester, 3, p. 131, 2005.

Han, S. C., Jekeli, C., and Shum, C. K.: Time-variable aliasing effects of ocean tides, atmosphere, and continental water mass on monthly mean GRACE gravity field, J. Geophys. Res., 109, B04403, doi:10.1029/2003JB002501, 2004.

Hornberger, G. M. and Spear, R. C.: An Approach to the Preliminary Analysis of Environmental Systems, J. Environ. Manage., $12,7-18,1981$.

Horwath, M. and Dietrich, R.: Errors of regional mass variations inferred from GRACE monthly solutions, Geophys. Res. Lett., 33, L07502, doi:10.1029/2005GL025550, 2006.

Houtekamer, P. L. and Mitchell, H. L.: Data Assimilation Using an Ensemble Kalman Filter Technique, Mon. Weather Rev., 126, 796-811, 1998.

Hunger, M. and Döll, P.: Value of river discharge data for globalscale hydrological modeling, Hydrol. Earth Syst. Sci., 12, 841861,2008 ,

http://www.hydrol-earth-syst-sci.net/12/841/2008/.

Kaspar, F.: Entwicklung und Unsicherheitsanalyse eines globalen hydrologischen Modells., Ph.D. thesis, Universität Kassel, 2004.

Kollat, J. B. and Reed, P. M.: Comparing state-of-the-art evolutionary multi-objective algorithms for long-term groundwater monitoring design, Adv. Water Resour., 29, 792-807, 2006.

Kollet, S. J. and Maxwell, R. M.: Capturing the influence of groundwater dynamics on land surface processes using an integrated, distributed watershed model, Water Resour. Res., 44, W02402, doi:10.1029/2007WR006004, 2008.

Kusche, J.: Approximate decorrelation and non-isotropic smoothing of time-variable GRACE-type gravity field models, J. Geodesy, 81, 733-749, 2007.
Legates, D. R. and Willmott, C. J.: Mean Seasonal and spatial variability in gauge-corrected global precipitation, Int. J. Climatol., 10, 111-127, 1990.

Lettenmaier, D. P. and Famiglietti, J. S.: Hydrology: Water from on high, Nature, 444, 562-563, 2006.

Liu, J., Williams, J. R., Zehnder, A. J., and Yang, H.: GEPIC modelling wheat yield and crop water productivity with high resolution on a global scale, Agr. Syst., 94, 478-493, 2007.

Liu, J., Zehnder, A. J. B., and Yang, H.: Global consumptive water use for crop production: The importance of green water and virtual water, Water Resour. Res., 45, W05428, doi:10.1029/2007WR006051, 2009.

Lo, M.-H., Yeh, P. J.-F., and Famiglietti, J.: Constraining water table depth simulations in a land surface model using estimated baseflow, Adv. Water Resour., 31, 1552-1564, 2008.

Lo, M.-H., Famiglietti, J. S., Yeh, P. J.-F., and Syed, T. H.: Improve parameter estimation and water table depth simulation in a land surface model using GRACE water storage and estimated baseflow data, Water Resour. Res., doi:10.1029/2009WR007855, in press, 2010.

Milly, P. C. and Shmakin, A. B.: Global modeling of land water and energy balances. Part I: The Land Dynamics (LaD) model, J. Hydrometeorol., 3, 283-299, 2002.

Nash, J. E. and Sutcliffe, J. V.: River flow forecasting through conceptual models part 1 - A discussion of principles, J. Hydrol., 10, 282-290, 1970.

Ngo-Duc, T., Laval, K., Ramillien, G., Polcher, J., and Cazenave, A.: Validation of the land water storage simulated by Organising Carbon and Hydrology in Dynamic Ecosystems (ORCHIDEE) with Gravity Recovery and Climate Experiment (GRACE) data, Water Resour. Res., 43, W04427, doi:10.1029/2006WR004941, 2007.

Niu, G.-Y., Yang, Z.-L., Dickinson, R. E., Gulden, L. E., and $\mathrm{Su}, \mathrm{H}$.: Development of a simple groundwater model for use in climate models and evaluation with Gravity Recovery and Climate Experiment data, J. Geophys. Res., 112, D07103, doi:10.1029/2006JD007522, 2007.

Papa, F., Güntner, A., Frappart, F., Prigent, C., and Rossow, W. B.: Variations of surface water extent and water storage in large river basins: A comparison of different global data sources, Geophys. Res. Lett., 35, L11401, doi:10.1029/2008GL033857, 2008.

Parajka, J. and Blöschl, G.: The value of MODIS snow cover data in validating and calibrating conceptual hydrologic models, J. Hydrol., 358, 240-258, doi:10.1016/j.jhydrol.2008.06.006, 2008.

Peel, M. C., Finlayson, B. L., and McMahon, T. A.: Updated world map of the Köppen-Geiger climate classification, Hydrol. Earth Syst. Sci., 11, 1633-1644, 2007, http://www.hydrol-earth-syst-sci.net/11/1633/2007/.

Priestley, C. H. and Taylor, R. J.: On the assessment of surface heat flux and evaporation using large-scale parameters, Mon. Weather Rev., 100, 81-92, 1972.

Reichle, R. H., McLaughlin, D. B., and Entekhabi, D.: Hydrologic Data Assimilation with the Ensemble Kalman Filter, Mon. Weather Rev., 130, 103-114, 2002.

Rodell, M., Houser, P. R., Jambor, U., Gottschalck, J., Mitchell, K., Meng, C. J., Arsenault, K., Cosgrove, B., Radakovich, J., Bosilovich, J. K. E. M., Walker, J. P., Lohmann, D., and Toll, D.: The Global Land Data Assimilation System, B. Am. Meteorol. Soc., 85, 381-394, 2004. 
Rodell, M., Chen, J., Kato, H., Famiglietti, J., Nigro, J., and Wilson, C.: Estimating groundwater storage changes in the Mississippi River basin (USA) using GRACE, Hydrogeol. J., 15, 159-166, 2007.

Savenije, H. H. G.: HESS Opinions “The art of hydrology"*, Hydrol. Earth Syst. Sci., 13, 157-161, 2009, http://www.hydrol-earth-syst-sci.net/13/157/2009/.

Schmidt, R., Schwintzer, P., Flechtner, F., Reigber, C., Güntner, A., Döll, P., Ramillien, G., Cazenave, A., Petrovic, S., Jochmann, H., and Wünsch, J.: GRACE observations of changes in continental water storage, Global Planet. Change, 50, 112-126, 2006.

Schmidt, R., Flechtner, F., Meyer, U., Neumayer, K. H., Dahle, C., König, R., and Kusche, J.: Hydrological signals observed by the GRACE satellites, Surv. Geophys., 29, 319-334, 2008a.

Schmidt, R., Petrovic, S., Güntner, A., Barthelmes, F., Wünsch, J., and Kusche, J.: Periodic components of water storage changes from GRACE and global hydrology models, J. Geophys. Res., 113, B08419, doi:10.1029/2007JB005363, 2008b.

Schulze, K. and Döll, P.: Neue Ansätze zur Modellierung von Schneeakkumulation und -schmelze im globalen Wassermodell WaterGAP, in: 7th Workshop for large-scale modeling, in: Hydrology. Munic, November 2003, edited by: Ludwig, R., Reichert, D., and Mauser, W., Kassel University Press, Kassel, 145154,2004

Seitz, F., Schmidt, M., and Shum, C. K.: Signals of extreme weather conditions in Central Europe in GRACE 4-D hydrological mass variations, Earth Planet. Sc. Lett., 268, 165-170, 2008.

Sheffield, J., Ferguson, C. R., Troy, T. J., Wood, E. F., and McCabe, M. F.: Closing the terrestrial water budget from satellite remote sensing, Geophys. Res. Lett., 36, L07403, doi:10.1029/2009GL037338, 2009.

Shuttleworth, W. J.: Evaporation, in: Handbook of hydrology, edited by: Maidment, D., McGraw-Hill Inc., 4.1-4.53, 1993.

Swenson, S. and Wahr, J.: Methods for inferring regional surfacemass anomalies from Gravity Recovery and Climate Experiment (GRACE) measurements of time-variable gravity, J. Geophys. Res., 107, 2193, doi:10.1029/2001JB000576, 2002.

Swenson, S., Famiglietti, J., Basara, J., and Wahr, J.: Estimating profile soil moisture and groundwater variations using GRACE and Oklahoma Mesonet soil moisture data, Water Resour. Res., 44, W01413, doi:10.1029/2007WR006057, 2008.

Syed, T. H., J. S., F., Rodell, M., Chen, J., and Wilson, C. R.: Analysis of terrestrial water storage changes from GRACE and GLDAS, Water Resour. Res., 44, W02433, doi:10.1029/2006WR005779, 2008.

Tang, Y., Reed, P., and Wagener, T.: How effective and efficient are multiobjective evolutionary algorithms at hydrologic model calibration?, Hydrol. Earth Syst. Sci., 10, 289-307, 2006, http://www.hydrol-earth-syst-sci.net/10/289/2006/.
Tapley, B. D., Bettadpur, S., Watkins, M., and Reigber C.: The gravity recovery and climate experiment: Mission overview and early results, Geophys. Res. Lett., 31, L09607, doi:10.1029/2004GL019920, 2004.

Vrugt, J. A., Gupta, H. V., Bastidas, L. A., Bouten, W., and Sorooshian, S.: Effective and efficient algorithm for multiobjective optimization of hydrologic models, Water Resour. Res., 39, 1214, doi:10.1029/2002WR001746, 2003.

Wahr, J., Swenson, S., Zlotnicki, V., and Velicogna, I.: Timevariable gravity from GRACE: First results, Geophys. Res. Lett., 31, L11501, doi:10.1029/2004GL019779, 2004.

Wahr, J., Swenson, S., and Velicogna, I.: Accuracy of GRACE mass estimates, Geophys. Res. Lett., 33, L06401, doi:10.1029/2005GL025305, 2006

Werth, S., Güntner, A., Petrovic, S., and Schmidt, R.: Integration of GRACE mass variations into a global hydrological model, Earth Planet. Sc. Lett., 277, 166-173, 2009a.

Werth, S., Güntner, A., Schmidt, R., and Kusche, J.: Evaluation of GRACE filter tools from a hydrological perspective, Geophys. J. Int., 179, 1499-1515, doi: 10.1111/j.1365-46X.2009.04355.x, 2009b.

Widen-Nilsson, E., Halldin, S., and Xu, C.-y.: Global water-balance modelling with WASMOD-M: Parameter estimation and regionalisation, J. Hydrol., 340, 105-118, 2007.

Winsemius, H. C., Savenije, H. H. G., Gerrits, A. M. J., Zapreeva, E. A., and Klees, R.: Comparison of two model approaches in the Zambezi river basin with regard to model reliability and identifiability, Hydrol. Earth Syst. Sci., 10, 339-352, 2006a, http://www.hydrol-earth-syst-sci.net/10/339/2006/.

Winsemius, H. C., Savenije, H. H. G., van de Giesen, N. C., van den Hurk, B. J. J. M., Zapreeva, E. A., and Klees, R.: Assessment of Gravity Recovery and Climate Experiment (GRACE) temporal signature over the upper Zambezi, Water Resour. Res., 42, W12201, doi:10.1029/2006WR005192, 2006b.

Wouters, B., Chambers, D., and Schrama, E. J.: GRACE observes small-scale mass loss in Greenland, Geophys. Res. Lett., 35, L20501, doi:10.1029/2008GL034816, 2008.

Yapo, P. O., Gupta, H. V., and Sorooshian, S.: Mulit-objective global optimization for hydrologic models, J. Hydrol., 204, 83 97, 1998.

Zaitchik, B. F., Rodell, M., and Reichle, R. H.: Assimilation of GRACE terrestrial water storage data into a land surface model: Results for the Mississippi River Basin, J. Hydrometeorol., 9, 535-548, 2008.

Zeng, N., Yoon, J.-H., Marengo, J. A., Subramaniam, A., Nobre, C. A., Mariotti, A., and Neelin, J. D.: Causes and impacts of the 2005 Amazon drought, Environ. Res. Lett., 3, 014002, doi:10.1088/1748-9326/3/1/014002, 2008. 